\title{
Effectiveness of the GAEC cross-compliance standard Short-term measures for runoff water control on sloping land (temporary ditches and grass strips) in controlling soil erosion
}

\author{
Paolo Bazzoffi, ${ }^{1}$ Arianna Ciancaglini, ${ }^{1}$ Nicola Laruccia² \\ ${ }^{1}$ CRA-ABP Agricultural Research Council, Agrobiology and Pedology Research Centre, Florence; \\ ${ }^{2}$ Freelancer Agronomist, Florence, Italy
}

\begin{abstract}
The agronomic measures made obligatory by the cross-compliance Standard Temporary measures for runoff water control on sloping land included in the Ministry of Agricultural, Food and Forestry Policies (MiPAAF) decree on cross compliance until 2008, and by Standard 1.1 Creation of temporary ditches for the prevention of soil erosion in the 2009 decree, certainly appear to be useful for the control of soil erosion and runoff. The efficacy of temporary drainage ditches ${ }^{1}$ and of grass strips $^{2}$ in controlling runoff and erosion has been demonstrated in trials conducted in field test plots in Italy. When level temporary drainage ditches are correctly built, namely with an inclination of not more than $2.5 \%$ in relation to the maximum hillslope gradient, they allow the suspended sediment eroded upstream to settle in the ditches, retaining the material carried away on the slope and, as a result, reducing the quantity of sediment delivered to the hydrographic network. In particular, among all the results, the erosion and runoff data in a trial conducted in Guiglia (Modena) showed that in corn plots, temporary drainage ditches reduced soil erosion by $94 \%$, from $14.4 \mathrm{Mg} \mathrm{ha}^{-1}$ year-1 (above the limit established by the NRCS-USDA of $11.2 \mathrm{Mg} \mathrm{ha}^{-1}$ year-1) to $0.8 \mathrm{Mg} \mathrm{ha}^{-1}$ year $^{-1}$ (within the NRCS limit and also within the more restrictive limit established by the OECD of $6.0 \mathrm{Mg} \mathrm{ha}^{-1}$ year ${ }^{-1}$ ). With respect to the grass
\end{abstract}

Correspondence: Paolo Bazzoffi, CRA-ABP Agricultural Research Council, Agrobiology and Pedology Research Centre, p.za M. D’Azeglio 30, 50121 Firenze, Italy.

Tel. +39.055.2491228 - Fax: +39.055 .241485 .

E-mail: paolo.bazzoffi@entecra.it

Key words: soil erosion, temporary ditches, GAEC standard, grass strips, cross compliance.

Acknowledgements: we greatly acknowledge Massimo Aglietti, of the CRAABP staff, for the peer review of the text in English.

Received for publication: 24 March 2011.

Accepted for publication: 4 May 2011.

(C) Copyright P. Bazzoffi et al., 2011

Under no circumstances figures can be used without prior written consent of the copyright owner.

Licensee PAGEPress, Italy

Italian Journal of Agronomy 2011; 6(s1):e3

doi:10.4081/ija.2011.6.s1.e3

This work is licensed under a Creative Commons Attribution NonCommercial 3.0 License (CC BY-NC 3.0). buffer strips the most significant research was carried out in Volterra. This research demonstrated their efficacy in reducing erosion from 8.15 $\mathrm{Mg} \mathrm{ha}^{-1}$ to $1.6 \mathrm{Mg} \mathrm{ha}^{-1}$, which is approximately 5 times less than the erosion observed on bare soil. The effectiveness of temporary drainage ditches was also assessed through the application of the Revised Universal Soil Loss Equation (RUSLE) erosion model to 60 areas under the control of the Agency for Agricultural Payments (AGEA) in 2009, comparing the risk of erosion in these sample areas by simulating the presence and absence of drainage ditches at a distance of 80 metres from each other as required by the Standard. The results of the scenario analysis showed that the presence of ditches on average decreases erosion by $67 \%$. To sum up, the Standard was found to be effective from a hydraulic point of view, as the results have demonstrated the adequacy of temporary ditches for the control of runoff water. Another important result of this study was the production of a simple equation that can be directly used by farmers or, more realistically, by the farm advisory system to provide farmers with the information necessary for the realisation of temporary drainage ditches (depth and section that can be obtained with the most widespread types of ditch diggers) so that these ditches are effective and maintain their hydraulic efficacy throughout the entire cropping period. This equation would also be useful for crosscompliance control by the AGEA and regional control bodies.

\section{Introduction}

\section{Legislation and aim of the study}

GAECs (Standards of Good Agricultural and Environmental Condition) form part of the requirements under cross compliance and apply to anyone who receives payments under the Single Payment Scheme. GAECs set requirements for farmers in respect of soils, as well as maintaining a range of habitat and landscape features that are characteristic of the Italian countryside. The GAEC standard Temporary measures for water runoff control on sloping land was made mandatory for arable land and was included in the Mipaaf decrees on cross compliance until 2008 (Rule 1.1) with the aim of ensuring protection of soil from erosion. The subsequent Decree 30125 of December 2009 maintained this Standard (named Standard 1.1a) under Rule 1 (soil-protection measures) with the same aim.

\footnotetext{
${ }^{1}$ Temporary drainage ditches: Ephemeral ditches which run across the slope in a transverse manner with a distance of not more than 80 metres from each other and with technical characteristics that ensure that the runoff "maintains a speed that does not compromise the function of the ditch itself"'

${ }^{2}$ Grass strips: $5-m$ grass strips that run across the slope in a transverse manner realized by way of derogation from the creation of drainage ditches and provided for by the Mipaaf decree.
} 
As indicated by the decree, the farmer's obligation consists in: The realisation of temporary drainage ditches, so that the collected rainwater, including runoff from the area uphill of the plot under consideration, maintains a speed that does not compromise the function of the ditch itself, and is carried away into the permanent channels and natural impluvia along the field border where these exist. This obligation applies to sloping land that shows erosive phenomena indicated by the presence of extensive rills in the absence of land set-up systems for soil and water conservation.

In this work, carried out in the context of the EFFICOND ${ }^{3}$ project, the efficacy of the temporary drainage ditches was assessed both with respect to their ability to control runoff in extreme rainfall events and with respect to their efficacy in decreasing the mean annual soil erosion. In addition, the efficacy of grass strips created by following the indications provided in the Mipaaf decree by way of derogation from drainage ditches as an alternative measure to temporary drainage ditches, was assessed.

${ }^{3}$ EFFICOND $(E F F=$ Effectiveness of environmental standards, $C O N D=$ Cross compliance $)$ is a CRA (Agricultural Research Council) project started in 2009 to meet the specific need of NRN (National Rural Network) to monitor and evaluate the effectiveness of environmental protection actions mandated by the CAP to national agricultural policy and implemented by the Regional Rural Development Plans (RDP). The main project objectives are the evaluation of GAEC standards implemented under cross compliance and the development of agrienvironmental indicators for nation-wide scenario analysis. The EFFICOND project involves 10 operational units with experimental fields located throughout the country.

\section{The GAEC standard in the framework of the Land Set-up Systems for soil and water con- servation in hilly areas}

The classical agricultural Land Set-up Systems for soil and water conservation $^{4}$ (Ridolfi, 1934; Calzecchi Onesti, 1957; Oliva, 1948a,b; Landi, 1979, 1980), at present almost anywhere disused, served the double purpose of regulating runoff water and reducing soil erosion without compromising the establishment of an adequate water supply necessary for the development of the crops (Landi, 1984). Among the systems adopted in the past on hillslopes, many of which still remain and enhance the beauty of the Italian countryside, the most well-known are: the girapoggio (circling the hill) system adopted for regular cone-shaped hills, where fields and level ditches spiral around the hill (Figure 1A); the fosse livellari (level ditches) system, which is the same as the girapoggio system, with the only difference of not being used on conical hills (Figure 1B); the cavalcapoggio (straddling the hill) system where broad fields with regular rows of trees and ditches do not follow the contour lines (Figure 1C); the rittochino system where the fields are set along the maximum hillslope gradient (Figure 1D); the $a$ spina system (now almost entirely disused) where fields and ditches follow a herring-bone layout (Figure 1E); the colmata di monte, which is a natural system of land levelling by inducing sedimentation in impluvia. The material that erodes in two contiguous fields which discharge runoff water into the same impluvium is forced to sediment in pools created by a number of earth micro-dams, which cascade along the same impluvium (Figure 1F).

${ }^{4}$ Land set-up systems for soil and water conservation $=$ Systems of surface setting of fields aimed to control runoff, stop soil erosion and landslides, avoid waterlogging, assure infiltration and optimize cultivation (classified in two main groups: flat-land and hilly Agrarian hydraulic land settings, in Italian: Sistemazioni idraulico agrarie).
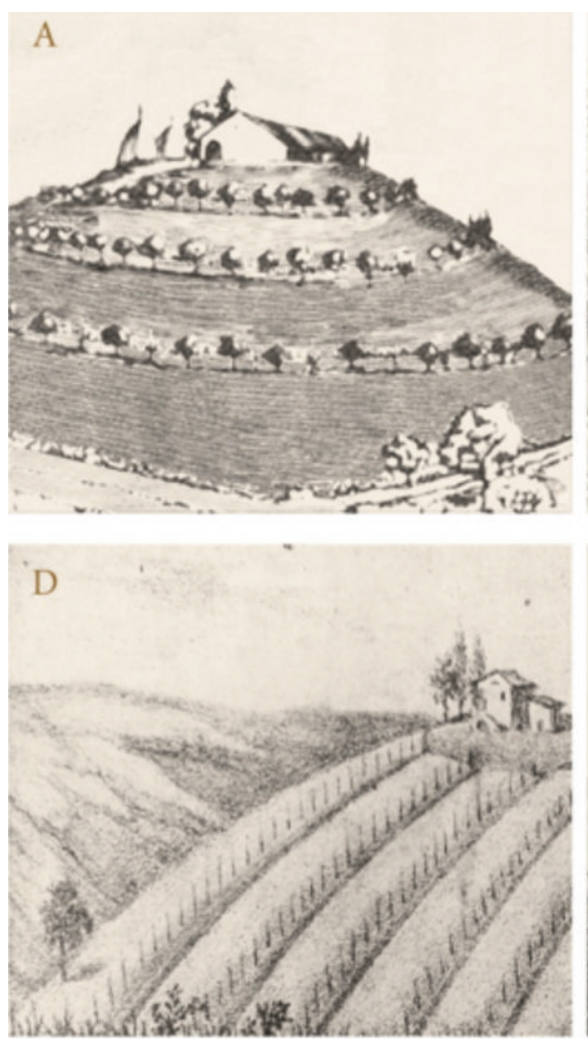
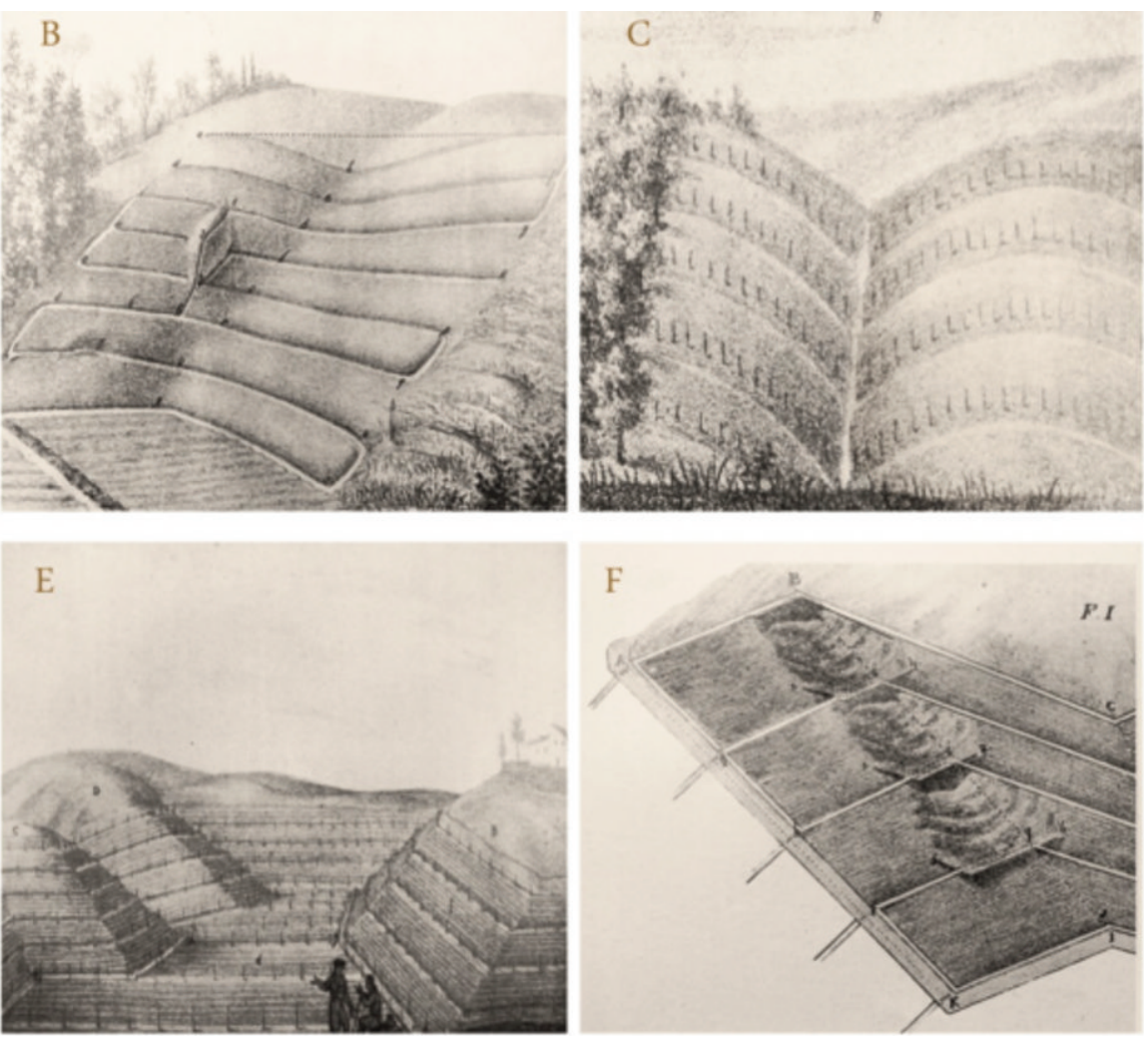

Figure 1. Italian most known Land Set-up Systems for soil and water conservation: (A) Girapoggio (Circling the hill); (B) fosse livellari (level ditches circling the hill) applied to other than conical hills; (C) cavalcapoggio (Straddling the hill); (D) rittochino (Along the maximum hillslope gradient); (E) spina (Set to a herringbone layout); (F) colmata di monte (Naturally induced sedimentation - now almost entirely disused) (partly extracted from the tables by Cosimo Ridolfi, 1934). 
Since the middle of the last century, the development of agriculture has been characterised by the abandonment of promiscuous crops and the increase of field surfaces, often in connection with the mechanical reshaping of the soil morphology in order to create slopes that are as uniform as possible to facilitate as much as possible the needs of modern agriculture.

Traditional agricultural land set-up systems on the hillsides were largely abandoned and starting in the period 1960-80 mechanisation made it necessary to develop systems more suitable than the old schemes to the necessities determined both by the size of today's fields and by full mechanisation of agricultural practices.

Already in 1970, Gasparini described the main characteristics of the modern land set-up system. He noted that the typical hillsides were interrupted by ditches (level channels) with a distance of about 100 metres from each other and a length of about 200 meters (Gasparini, 1970). This new land setting scheme is based on a system of drainage channels whose depth, on average 40-60 cm, exceeds the ploughing depth by about $10 \mathrm{~cm}$. These drainage channels, which run across the slope in a transverse manner with a slight gradient of $1.5-2.5 \%$ depending on the morphology of the terrain, intercept both surface and ground water and then discharge it into the river network. In its classic model, this scheme required fields of 2.5-3 ha, as the ditches could be at most $250 \mathrm{~m}$ long and have a distance of $80-120 \mathrm{~m}$ from each other (Gasparini, 1959, 1964, 1970; Periccioli, 1956).

The agronomic practice indicated by the GAEC Standard takes into account the above mentioned studies that created the new water-management designs developed in the years 1960-80, and requires the realisation of temporary drainage ditches with a distance of not more than 80 metres from each other and with technical characteristics that ensure that the runoff maintains a speed that does not compromise the function of the ditch itself (Figure 2).

The GAEC standard temporary ditches is similar to the fosse livellari land set-up system, which has been widely recognised as being highly effective in controlling runoff and soil erosion. The reason why the fosse livellari system is no longer applied and was not adopted by the crosscompliance Decree is because it is too expensive. In addition, it is almost always not sustainable in the modern agriculture due to the excessive proximity of ditches to each other and their strict location on level curves can disturb the operations of agricultural machinery and, on steep slope, expose the tractor to the risk of overturning. Temporary ditches, as described and made mandatory by the GAEC Standard, can be regarded as a simplification of the fosse livellari system. So, despite the fact that the temporary ditches might be less effective than the fosse livellari system, they have some advantages, such as: lower cost (economic sustainability), less specialized labour (i.e. planning) and agricultural machinery requested to realise them.

For these reasons the GAEC Standard can be considered the best compromise to control erosion with the commonly used farm machinery and, at once, at acceptable costs. On the other hand, as a general rule, the agronomic actions a farmer should take to comply with the GAEC standards are minimal and just serve to keep the environmental menace (in this case represented by soil erosion) within the tolerance threshold. Thus, the fosse livellari land set-up system can be proposed as a greater commitment than the cross compliance temporary ditches, that might be implemented under the second pillar of CAP (agro-environment), among the agri-environmental measures aimed to soil conservation, to be adopted on voluntary basis by farmer. The environmental efficacy of this reference standard, that is the efficacy of the temporary ditches, must be assessed by looking at the double aspect of the efficacy both in intercepting all of the runoff water at the peak discharge and in reducing soil erosion to the tolerance limits. To this end it is important to remember that the erosion tolerance threshold cannot be established solely in terms of a precise value $\left(\mathrm{Mg} \mathrm{ha}^{-1}\right.$ year $\left.{ }^{-1}\right)$ considered valid for all soils and situations. The erosion tolerance limit should be established considering the dangerousness, the vulnerability and the exposed value, hence taking into account the different nature and fragility of the soils, their economic value and the off-site effects of erosion

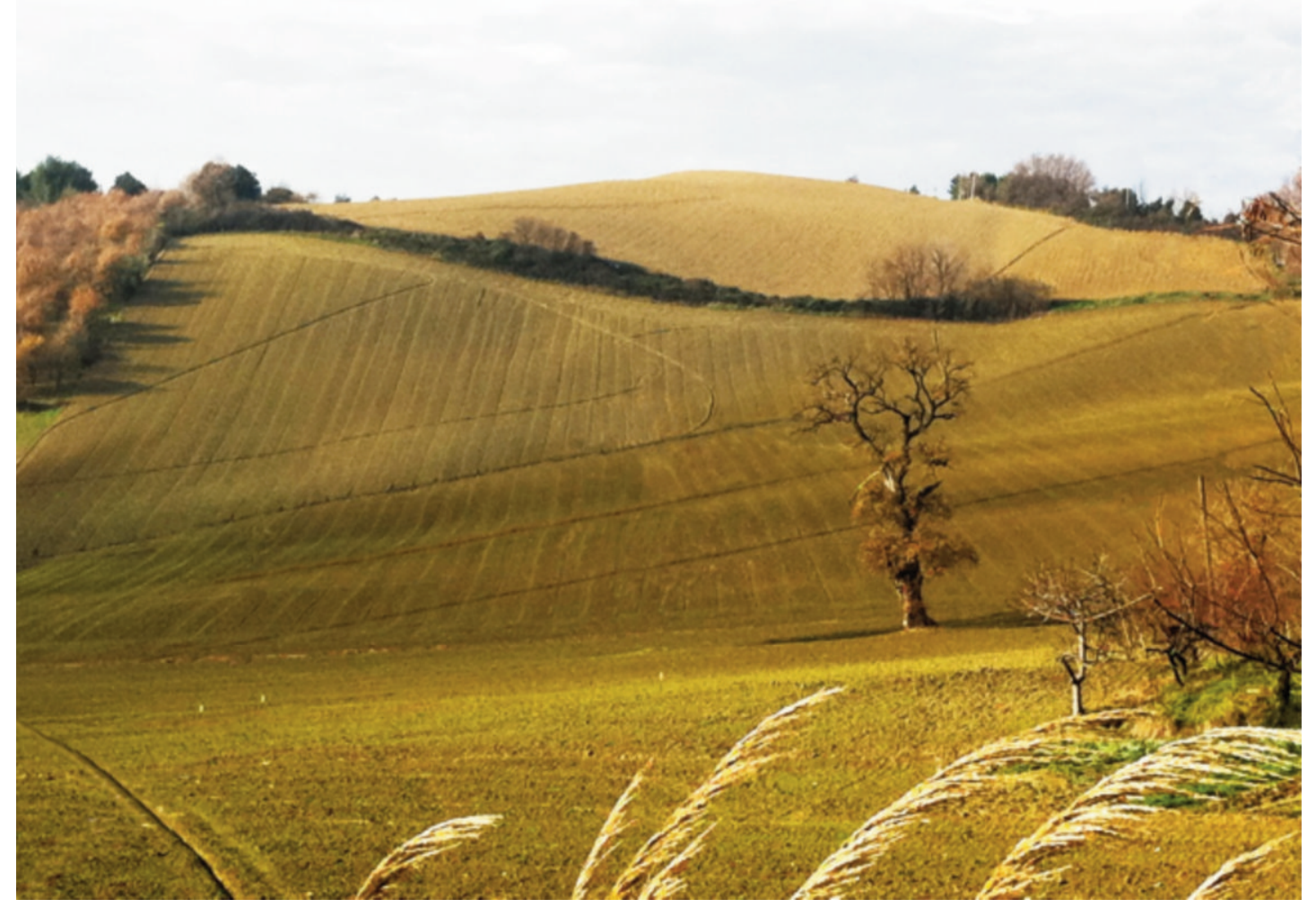

Figure 2. Temporary drainage ditches realised to comply with the cross-compliance standard (by courtesy of $L$. Rossi, SIN-AGEA). 
(Bazzoffi, 2009). Despite these new perspectives, at the current state it is considered necessary for the cross-compliance regulation to refer to the limit of $11.2 \mathrm{Mg} \mathrm{ha}^{-1}$ year-1, considered the acceptable maximum in the United States (NRCS-USDA, 1999) or to the limit of $6 \mathrm{Mg} \mathrm{ha}^{-1}$ year-1 set by the OECD (2001). The drainage channels' ability to intercept all of the runoff water and carry it towards the secondary water-collection network is of the utmost importance. In fact, if the drainage channels are too small, the runoff water easily causes the destruction of the temporary ditches, accelerating erosion in the area downhill. The water that flows ruinously from the ditch's point of collapse can also destroy the ditches further downhill, leading to a cascade effect (Figure 3). Considering that soil erosion is linked directly to the runoff volume (Bagarello et al., 2009; Mannocchi et $a l ., 2009)$, the correct size and distance of the drainage channels is important with respect to their ability to intercept the water coming from the area between two drainage channels, reducing the speed and permitting the sedimentation of the eroded material. These considerations make it imperative that water management with level ditches must be carried out up to standards, otherwise it will worsen the situation and accelerate soil erosion. In this work, the efficacy of the temporary drainage ditches was therefore assessed both with respect to their ability to control runoff in heavy rain situations and with respect to their efficacy in decreasing the mean annual soil erosion in the test areas. In addition, the efficacy of grass strips created as an alternative measure to temporary drainage ditches, as indicated in the cross-compliance decrees, was assessed.

\section{Study of experimental cases}

\section{Water-management efficacy of temporary drainage ditches: determination of peak runoff values that must be controlled by the drainage ditches}

To assess the efficacy of the drainage ditches in controlling runoff it is necessary to know the water volumes that the ditch must drain off at peak discharge moments (Landi et al., 1982). Current climatic changes, characterised by an increase in the frequency of extreme events (Bazzoffi and Pellegrini, 1992; Buffoni et al., 2003), make it advisable to determine the size of the primary channel network ${ }^{5}$ on the basis of runoff peaks rather than mean annual values.

With regard to this, it must be said that there is little experimental observation in Italy, and the few research studies carried out at the level of individual plots or hillsides, both in the past and currently, were aimed at the fine-tuning and development of erosion models in limited areas of the Italian territory.

${ }^{5}$ Ditches in the fields can be divided into primary and secondary channel networks. The primary network is made up of the drainage ditches, which are the temporary channels created on the fields for the time from sowing to harvest. The secondary network is permanent, collects the water coming from the drainage ditches and carries it into natural rainwater basins or into artificial channels.

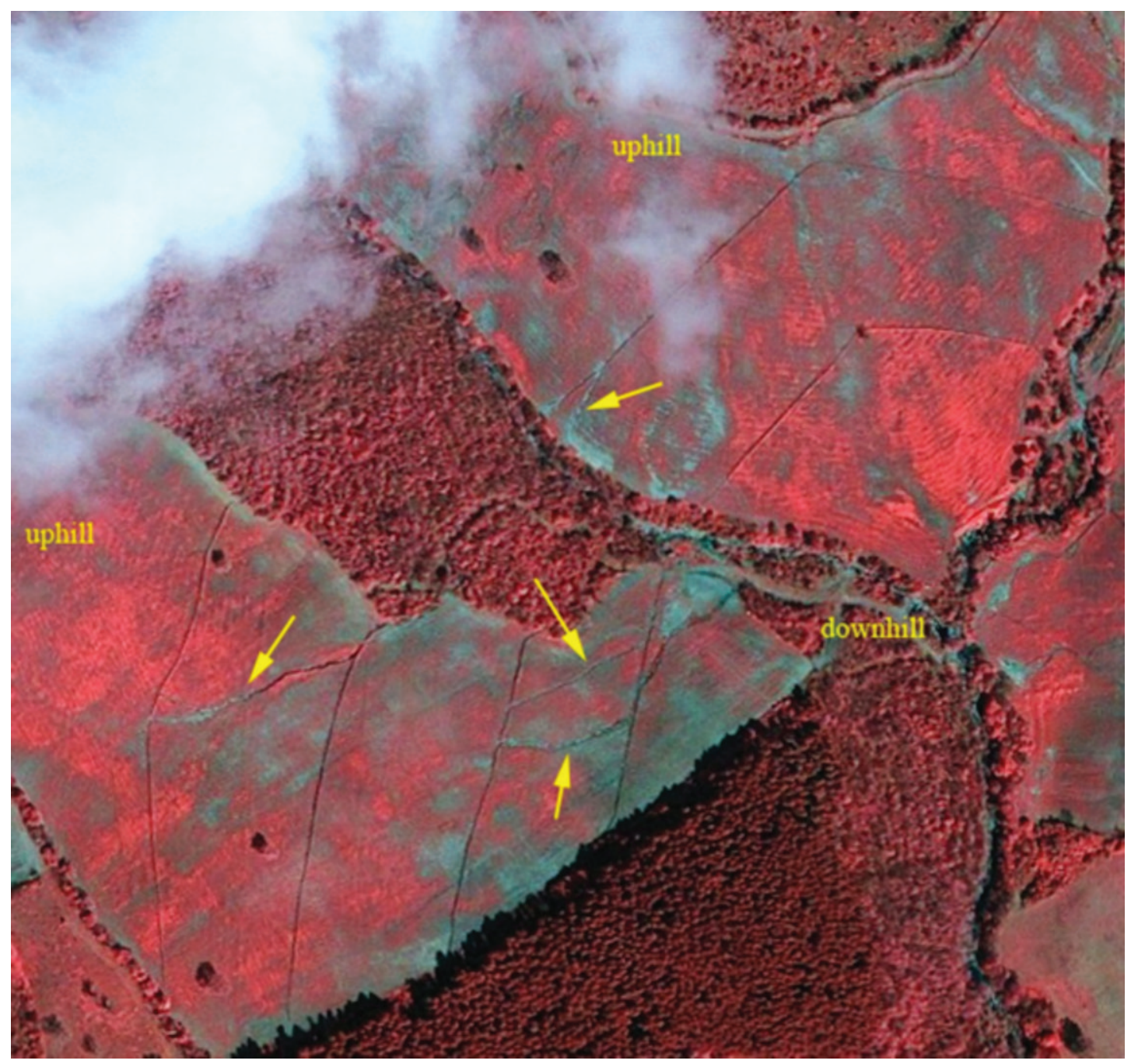

Figure 3. Temporary drainage ditches (Grosseto Province, Spring 2009). Yellow arrows show the accelerated erosion caused by the collapse of the ditches due to their insufficient runoff discharge capacity. Ikonos Satellite image, $1 \mathrm{~m}$ resolution (in false colours) (by courtesy of SIN-AGEA). 
The data published in the context of these studies show the total runoff volumes generated by rainfall and do not concern runoff peak volumes that occurred during the events. There are very few studies whose aim is the direct verification of the functionality of drainage ditches.

In general, in Italy the size of the channel network is determined using a few equations for the calculation of peak runoff volumes. The most well-known of these is the rational method (Chow, 1964):

$$
\mathrm{Q}=0.0028 \cdot \mathrm{C} \cdot \mathrm{I} \cdot \mathrm{A}
$$

where $Q$ is the peak runoff $\left(\mathrm{m}^{3} \mathrm{~s}^{-1}\right)$ of the catchment basin, $C$ is the runoff coefficient (dimensionless), I is the rain intensity $\left(\mathrm{mm} \mathrm{h}^{-1}\right)$ corresponding to the basin's lag time, and A is the basin's area (ha). This equation is used assuming that the rain intensity is constant and corresponds to the basin's lag time. For this reason, the rational method is not always completely reliable.

On the other hand, the rainfall and runoff data obtained from research studies conducted by various research Institutions in Italy from the 1970s until today are more interesting.

In the context of the sub-project Hillside dynamics of the Soil conservation project carried out by the CNR (Italian National Research Council), an experiment was carried out in Figline Valdarno that provided data about runoff peaks (Landi et al., 1982). This experiment concerned a hillslope characterised by sandy loam soil (58.7\% sand content) and with an average gradient of $16 \%$, where runoff data were collected in four large hydraulically isolated plots that were $20 \mathrm{~m}$ wide and 80 or $50 \mathrm{~m}$ long, with ploughing depths of 50 or $30 \mathrm{~cm}$.

In this area, the analysis of the runoff peaks for the critical event on $4^{\text {th }}$ November 1980 (following a rainstorm that reached a maximum of $39 \mathrm{~mm}$ within one hour) showed a maximum value of $0.037 \mathrm{~m}^{3} \mathrm{~s}^{-1} \mathrm{ha}^{-1}$ on the plots with a ploughing depth of $50 \mathrm{~cm}$, while the peak runoff on the plots with a ploughing depth of $30 \mathrm{~cm}$ was $0.071 \mathrm{~m}^{3} \mathrm{~s}^{-1} \mathrm{ha}^{-1}$.

In Guiglia (Modena), the former Agronomic Institute (now CRA) carried out a series of research studies from 1976 to 1983 in two small uniform catchment basins of 1.5 ha with a gradient of $13 \%$ (clay soil Vertic Eutrochrept). In this experimental station, the maximum peak runoff was observed during the event of 22 June 1981 and had a value of $0.0333 \mathrm{~m}^{3} \mathrm{~s}^{-1} \mathrm{ha}^{-1}$ (Chisci and Boschi, 1988). These values are in line with the ones observed in Vicarello (Volterra) at the CRA-ABP experimental farm in the context of the Mipaaf project PANDA and during subsequent research studies, for a total of 10 years' worth of recorded data. Since the 1960 's, this experimental farm, characterised by silty clay vertisols, is hosting 8 hydraulically isolated and equipped plots that collect the runoff of an entire hillslope. The plots are $75 \mathrm{~m}$ long on the highest gradient and $15 \mathrm{~m}$ wide, with a gradient of $25 \%$. They are equipped with electronic hydrological units that record the runoff values using a tipping bucket sensor (Bazzoffi, 1993a and 1993b). This device allows extremely detailed data acquisition (one record for each tipping of the bucket).

It should be noted that the mean runoff value and the maximum peak (Table 1) were 3.1 and 2.7 times less, respectively, than the values estimated with the rational method. The maximum peak was observed during an exceptional rainfall of $56.8 \mathrm{~mm}$ on $19^{\text {th }}$ February 1996 , with a maximum intensity of $54 \mathrm{~mm} \mathrm{~h}^{-1}$ in 2 minutes. At the same time when the hydrological measurements were carried out in the above plots, two monocultural sub-basins of 4.66 ha and 5.62 ha were monitored at Vicarello; these were planted with alfalfa (Medicago sativa L.) (longestablished field) and durum winter wheat (Triticum durum Desf.), respectively. The maximum runoff peak values were observed in the years 1993-1994 with values of 0.031 and $0.037 \mathrm{~m}^{3} \mathrm{~s}^{-1} \mathrm{ha}^{-1}$, respectively, for the alfalfa field and for the wheat field. During a previous study carried out by the CRA-ABP (formerly ISSDS) from 1971 to 1972 in two small catchment basins of $1.06 \mathrm{~km}^{2}$ and $0.91 \mathrm{~km}^{2}$, respectively, in the calanchi badlands landscape around Volterra, the maximum peaks observed were 0.0191 and $0.0193 \mathrm{~m}^{3} \mathrm{~s}^{-1} \mathrm{ha}^{-1}$ (Bazzoffi et al., 1997). During a research study carried out from 1975 to 1979 (Zanchi, 1981) at the CRA-ABP farm in Fagna (Scarperia, Florence) on an entire hillside with an average gradient of $12.4 \%$ (clay soil, Typic Udorthent), the following maximum runoff values were observed: $0.0022,0.0057$ and $0.0060 \mathrm{~m}^{3} \mathrm{~s}^{-1} \mathrm{ha}^{-1}$ on three plots respectively set up as follows: pasture with normal stocking rate (1.01 ha), overgrazed (1.24 ha) and mowed (1.15 ha). Studies conducted on a small catchment basin of 3.67 ha with an average gradient of $19.5 \%$ and with clay soil (Vertic Xerochrept) in Sparacia, near Palermo, Sicily, showed a maximum runoff peak of $0.0046 \mathrm{~m}^{3} \mathrm{~s}^{-1} \mathrm{ha}^{-1}$ during the period 2004-2006 (Di Stefano et al., 2008, and personal communication of Vincenzo Bagarello, University of Palermo). In a small catchment basin of 1.47 ha with an average gradient of $35 \%$ near Crotone, Calabria, runoff values were monitored during the two periods from 1978 to 1994 and from 2008 to date. The highest runoff value of $0.171 \mathrm{~m}^{3} \mathrm{~s}^{-1} \mathrm{ha}^{-1}$ was observed on 26 September 2009 (personal communication of Paolo Porto of the University Mediterranea, Reggio Calabria). From 1992 to 1998, the Academy of Agriculture of Vezzolano (TO) carried out research on runoff in a vineyard with silty clay loam soil located on a hillside with a gradient of about $10 \%$. In the vineyard, two plots of about $5500 \mathrm{~m}^{2}$ each were hydraulically isolated. During the seven years of observation, 101 events with runoff values above $300 \mathrm{~L} \mathrm{ha}^{-1}$ were analysed. The maximum runoff peak was observed during the critical event of 25 September 1993, with a value of $12.2 \mathrm{~mm} \mathrm{~h}^{-1}$, corresponding to 0.0339 $\mathrm{m}^{3} \mathrm{~s}^{-1} \mathrm{ha}^{-1}$ (Lisa and Parena, 1994). After the collected data had been processed, the following equation, which is valid for the Italian territory, was obtained for the estimation of the maximum runoff peak in relation to the catchment basin's area and to the gradient:

$$
P=e^{a+b \cdot \ln x+c \cdot y^{3}}
$$

where

$p=\mathrm{m}^{3} \mathrm{~s}^{-1} \mathrm{ha}^{-1}$

$x$ is the area (ha);

$y$ is the mean hillslope gradient (\%).

Table 2 shows the graph of the equation and the statistical analysis of the model with the values of parameters $a, b$ and $c$ of equation (2).

Table 1. Mean runoff values and maximum peak observed at the plot installation of the CRA-ABP in Vicarello (Volterra), and values estimated with the rational method.

\begin{tabular}{lcccccccc} 
& Number of runoff events & & $\mathrm{m}^{3} \mathrm{~s}^{-1} \mathrm{ha}^{-1}$ & & \\
& & Mean & Std. Dev. & C.L. $-95 \%$ & C.L. +95\% & Median & Max \\
Q (Rational method) & 643 & 0.0389 & 0.0454 & 0.0354 & 0.0424 & 0.0205 & 0.2254 \\
Q (observed) & 643 & 0.0124 & 0.0191 & 0.0109 & 0.0139 & 0.0027 & 0.0833 \\
\hline
\end{tabular}

Original data (P. Bazzoffi) 


\section{Determination of the size and distance of the drainage ditches}

There are no technical manuals with precise indications, valid for Italy, regarding the suitable size for the field channel network. The only available indications are provided by Gasparini (1970) and Landi (1978) who report the following technical parameters for level ditches: depth of level ditch 5-10 cm greater than the ploughing depth; distance between ditches $60-100 \mathrm{~m}$; gradient of the bottom of the ditch 1.5-2.5\%; length of ditch not above $200 \mathrm{~m}$; presence of a network of water channels and natural impluvia to receive the water collected by the drainage ditches.

Oliva (1938) suggested the difference in elevation between two contiguous ditches in the fosse livellari land set-up system should not exceed 4-5 meters (Figure 4). Therefore, the calculation of the distance between ditches is obtained using the following empirical formula:

$$
\text { Distance }(\mathrm{m})=\quad \frac{4.5}{\text { slope }(\text { decimal })}
$$

From the application of the formula (3) it can be easily deduced that the fosse livellari land set-up system imposes a very short distance between ditches (e.g., for 0.15 slope the distance is equal to $30 \mathrm{~m}$ only). To assess the efficacy of the temporary drainage ditches realised by following the standard, it is necessary to compare their maximum flow discharge capacity $\left(\mathrm{m}^{3} \mathrm{sec}^{-1}\right)$ with the maximum runoff peak values calculated using equation (2), considering the area of the draining surface between two neighbouring ditches in relation to the length of the

Table 2. Model for the prediction of the maximum runoff peak $\left(\mathrm{m}^{3}\right.$ $\mathrm{ha}^{-1} \mathrm{~s}^{-1}$ ) based on the size and gradient of the catchment basin.

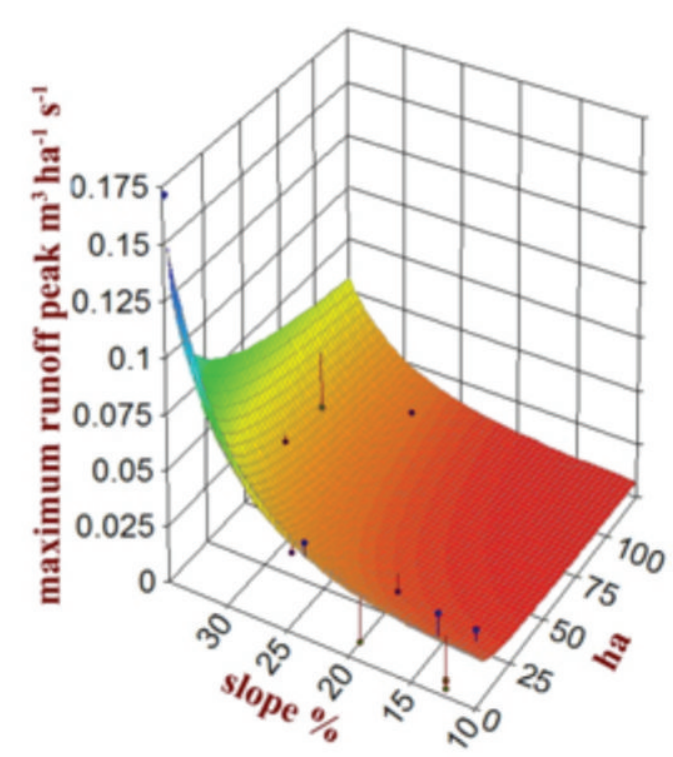

\begin{tabular}{ccccccc}
\hline Coeff. & B & St.Err.B & t-val. & $\begin{array}{c}\text { C.L. } \\
+95 \%\end{array}$ & $\begin{array}{c}\text { C.L. } \\
-95 \%\end{array}$ & p \\
\hline a & -3.737 & 0.217 & 17.227 & 4.221 & 3.254 & 0.00000 \\
b & -0.248 & 0.073 & 3.400 & 0.411 & 0.086 & 0.00677 \\
c & 4.793 e-05 & 6.103 e-06 & 7.853 & $3.433 \mathrm{e}-05$ & $6.153 \mathrm{e}-05$ & 0.00001 \\
& & & & & & \\
& $\mathrm{R}^{2}=\mathbf{0 . 8 9}$ & $\mathrm{R}^{2}$ Adg. $=0.86$ & St. Err. $=0.01627$ & $\mathrm{~F}=42.20$
\end{tabular}

\begin{tabular}{cccccc}
\hline Source & SS & DF & MS & F & p \\
Regression & 0.022 & 2 & 0.011 & 42.20 & 0.00001 \\
Error & 0.003 & 10 & 0.0003 & & \\
Total & 0.025 & 12 & & & \\
\hline
\end{tabular}

ditch and the gradient of the slope. The equations according to Chézy (1776) and Bazin (1897) were used as follows to calculate the ditch's maximum discharge capacity:

$$
\text { Chézy: } Q=C \cdot A \sqrt{R \cdot I} \quad \text { Bazin: } C=\frac{87 \cdot \sqrt{R}}{\gamma+\sqrt{R}}
$$

Where

$Q=\mathrm{m}^{3} \sec ^{-1}$

$A=$ Area in $\mathrm{m}^{2}$;

$R=$ hydraulic radius;

$\gamma=1.75$ (Monotti, 1980);

$I$, is the gradient of the bottom of the ditch $(=0.025)$.

The maximum flow discharge values shown in Table 3 are obtained for ditches excavated using a ditcher or a digging plough.

Table 4 shows the maximum runoff peak values calculated using equation (2) for the draining surface between two neighbouring ditches in relation to the length of the ditch and the gradient of the slope up to a maximum of $25 \%$. Beyond this gradient, level ditches are not feasible due to the instability of the tractor. By comparing the maximum runoff peak values generated by agricultural surfaces (Table 4) to the maximum discharge capacity of the various types of drainage ditches (Table 3), it is possible to determine the minimum values for the ditch size required to control runoff according to site-specific conditions.

Table 3. Maximum flow discharge capacity of various types of drainage ditches excavated to different depths with ditchers or digging ploughs.

\begin{tabular}{llc} 
Ditcher & $\begin{array}{c}\text { Depth } \\
\text { cm }\end{array}$ & $\begin{array}{c}\text { Ditch's } \\
\text { maximum } \\
\text { discharge } \\
\text { capacity } \text { m }^{3} \mathrm{~s}^{-1}\end{array}$ \\
Mono-wheel rotary ditcher (wheel diameter $30 \mathrm{~cm})$ & 15 & 0.0180 \\
Mono-wheel rotary ditcher (wheel diameter $32 \mathrm{~cm})$ & 16 & 0.0218 \\
\hline Mono-wheel rotary ditcher (wheel diameter $40 \mathrm{~cm})$ & 15 & 0.0238 \\
Mono-wheel rotary ditcher (wheel diameter $40 \mathrm{~cm})$ & 20 & 0.0418 \\
\hline Double-wheel rotary ditcher $\left(30^{\circ} \mathrm{V}\right.$-shaped ditch) & 20 & 0.0375 \\
Double-wheel rotary ditcher $\left(30^{\circ} \mathrm{V}\right.$-shaped ditch) & 30 & 0.0841 \\
\hline
\end{tabular}

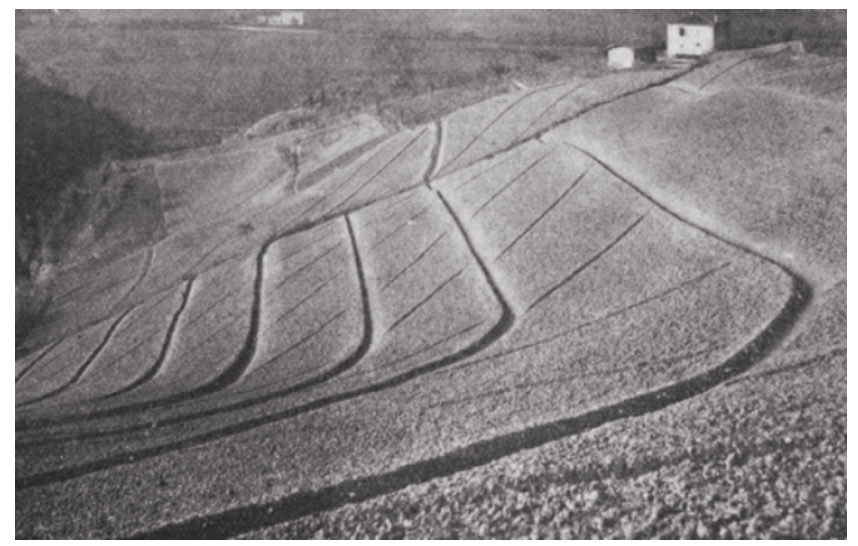

Figure 4. The Fosse livellari system (level ditches circling the hill) is no longer applied because off the excessive cost and labour required. It also subtracts too much soil from cultivations, causing problems to the agricultural machinery operativeness due to the interruption in the hillslope continuity (photo from Ridolfi, 1938). 

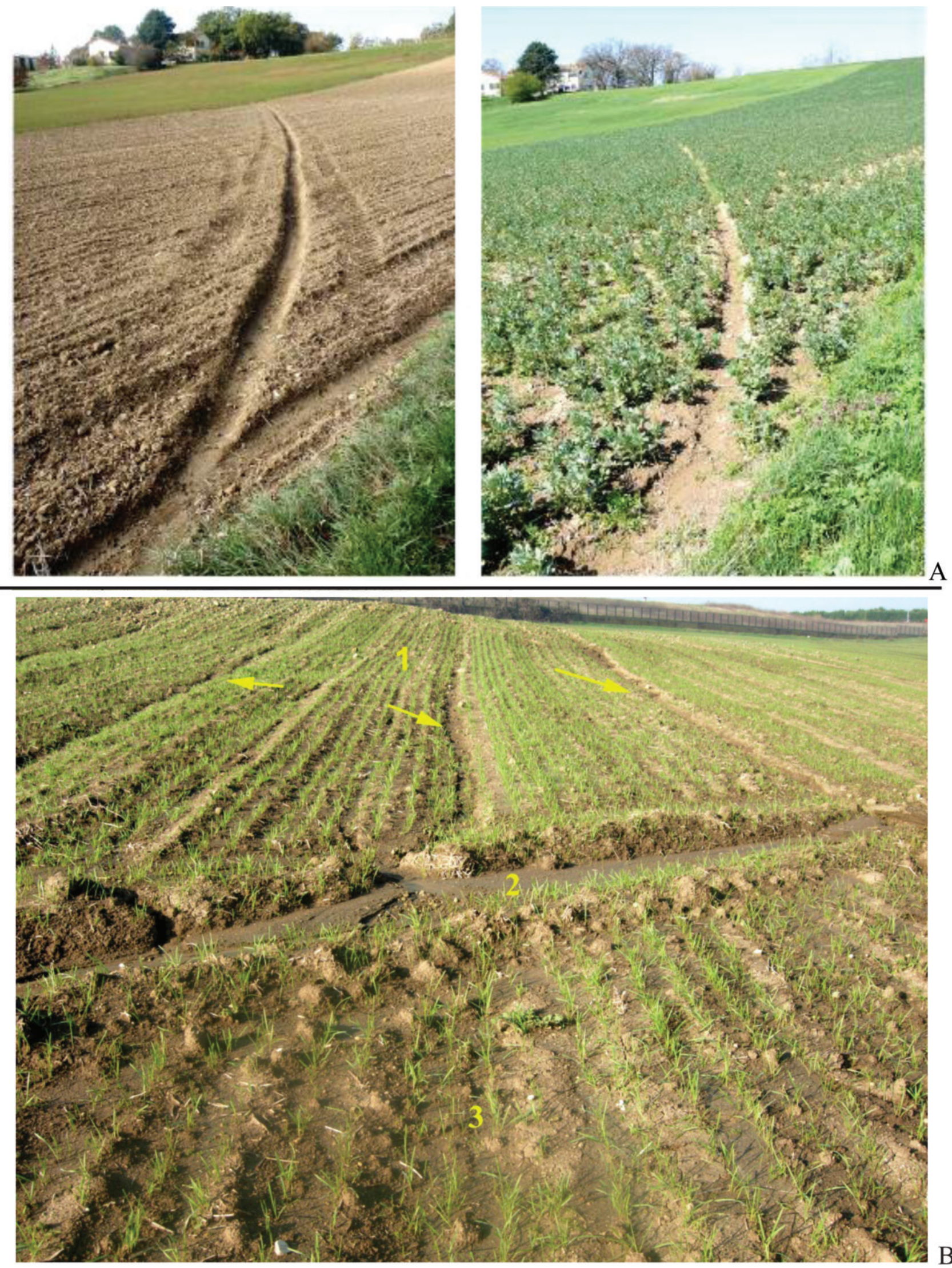

Figure 5. A) Temporary drainage ditch at Fagna (Florence, Italy) immediately after its creation (on the left - photo October 2009) and at the end of the experiment (on the right - photo April 2010). Note the deposition of sediment inside the ditch that indicates the retention of the eroded material on the hillslope. B) Temporary ditch at Monterotondo (Rome, Italy, spring 2009); 1) up the ditch zone with rills; 2) ditch filled by sediment; 3) down the ditch zone with no rills. 
Table 4. Maximum runoff peak values $\left(\mathrm{m}^{3} \mathrm{~s}^{-1}\right)$ calculated using equation (2) for the draining surface between two neighbouring drainage ditches in relation to ditch length, slope gradient and distance between ditches.

\begin{tabular}{|c|c|c|c|c|c|}
\hline $\begin{array}{l}\text { Inclined } \\
\text { distance between } \\
\text { ditches }\end{array}$ & $\begin{array}{l}\text { Length } \\
\text { of the ditch } \\
\text { m }\end{array}$ & $\begin{array}{l}\text { Me: } \\
10 \% \\
\mathrm{~m}^{3} \mathrm{~s}^{-1}\end{array}$ & $\begin{array}{l}\text { gradie } \\
15 \% \\
\mathrm{~m}^{3} \mathrm{~s}^{-1}\end{array}$ & $\begin{array}{c}\text { harge } c \\
20 \% \\
\mathrm{~m}^{3} \mathrm{~s}^{-1}\end{array}$ & $\begin{array}{c}25 \% \\
m^{3} s^{-1}\end{array}$ \\
\hline \multirow[t]{5}{*}{$80 \mathrm{~m}$} & 50 & 0.013 & 0.014 & 0.018 & 0.025 \\
\hline & 100 & 0.021 & 0.024 & 0.030 & 0.043 \\
\hline & 150 & 0.029 & 0.032 & 0.040 & 0.058 \\
\hline & 200 & 0.036 & 0.040 & 0.050 & 0.072 \\
\hline & 250 & 0.042 & 0.047 & 0.059 & 0.085 \\
\hline $60 \mathrm{~m}$ & $\begin{array}{c}50 \\
100 \\
150 \\
200 \\
250\end{array}$ & $\begin{array}{l}0.010 \\
0.017 \\
0.023 \\
0.029 \\
0.034\end{array}$ & $\begin{array}{l}0.011 \\
0.019 \\
0.026 \\
0.032 \\
0.038\end{array}$ & $\begin{array}{l}0.014 \\
0.024 \\
0.032 \\
0.040 \\
0.047\end{array}$ & $\begin{array}{l}0.020 \\
0.034 \\
0.047 \\
0.058 \\
0.068\end{array}$ \\
\hline
\end{tabular}

In addition, more restrictive criteria were applied during this study, considering the section of the ditches at the end of the experiment, which is the residual geometry at the end of winter, when the ditches no longer show their initial depth and the sides have been partly degraded by rainfall and runoff (Figure 5 ).

The mean values of the size of the drainage ditches were determined during a survey carried out at the CRA-ABP experimental farms in Vicarello and Fagna in June 2010 (Table 5). A greater number of observations would be needed to determine the percentage of degradation of the discharge capacity of various types of ditches in various environments of the Italian territory. However, in order to handle runoff peaks that may occur at the end of the agricultural year, when the ditches have reached their maximum level of degradation, the size of the drainage ditches must be established taking into account as an approximation a reduction of the discharge capacity by 25 to $30 \%$ as shown in Table 5 .

The partial obstruction of the ditches should not be considered only in a negative light. In fact, the primary channel network also serves to capture the sediments, meaning that less eroded soil is carried downhill and the soil thus remains on the site (Figure 1).

\section{Results of plot studies conducted in Italy}

\section{Efficacy of drainage ditches in controlling soil erosion}

The only field study conducted in Italy to assess the ditches' efficacy in controlling soil erosion is the already mentioned study carried out from 1976 to 1983 in Guiglia (Modena) at the Bombere experimental farm by the former Agronomic Institute (now CRA) on two small catchment basins of 1.5 ha each with a uniform gradient of $13 \%$ created by levelling the terrain (clay soil, Vertic Eutrochrept) (Chisci and Boschi, 1988).

Four level ditches were created at a distance of 33 meters from each other in the basin with drainage ditches, while the basin without ditches consisted in a single slope with a length of $132 \mathrm{~m}$.

The erosion and runoff data showed that in corn fields the drainage ditches reduce soil erosion by $94 \%$ and runoff by $32 \%$ (Figure 6 ). In particular, erosion was reduced from $14.4 \mathrm{Mg} \mathrm{ha}^{-1}$ year-1 $^{-1}$ (above the OECD

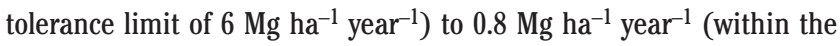
tolerance limit). In the trial conducted in Guiglia, the distance between the ditches was less than the $80 \mathrm{~m}$ required by the minimum requirement of GAEC standard 1.1; nevertheless, the results are highly indicative of the Standard's efficacy.
Table 5. Degradation of the drainage ditches at the CRA-ABP experimental farms in Vicarello and Fagna (Italy). Ditches realized with a mono-wheel rotary ditcher (wheel diameter $40 \mathrm{~cm}$ ).

\begin{tabular}{|c|c|c|c|c|}
\hline & \multicolumn{2}{|c|}{ Fagna } & \multicolumn{2}{|c|}{ Vicarello } \\
\hline & Initial & Final & Initial & Final \\
\hline Discharge capacity $\mathrm{m}^{3} \mathrm{~s}^{-1}$ & 0.0248 & $0.0154 \pm 0.004$ & 0.0172 & $0.0104 \pm 0.005$ \\
\hline
\end{tabular}

Vicarello ditches: final loss of discharge capacity $=28.2 \%$

\section{Efficacy of tillage in reducing erosion}

With respect to the GAEC cross-compliance commitments, it is very important to emphasise the synergy between the way the soil is tilled and the presence of temporary ditches for the control of runoff and erosion.

On sloping land with a silty clay loam texture, tilling of the soil can also contribute efficiently to the protection of soil from erosion if it is carried out according to precise patterns that depend on the weather and on the characteristics of the site. In particular, on these soils it is necessary to carry out tilling in in good workability conditions, as this facilitates the formation of macro and microaggregates with good stability that allow water infiltration and consequently the decrease of runoff (Landi, 1984). As emphasised also by Landi (1984), it is obviously necessary to have an overall view of the problems that concern the various agricultural areas of the Italian territory. For this reason, a generalised assertion that tillage decreases runoff and erosion is not always possible. In particular, with respect to Standard 1.1 it is necessary to take into account also the effect of tillage on slope stability and on the risk of surface landslides that can be caused by an excessive gradient and by an excess of water at the interface between the plough layer and the plough pan. Limiting the investigation to the effects of tillage on runoff and erosion leads to the results of a study conducted between 1982 and 1984 by Basso et al. (1986) in a hilly area of the Basilicata region (700 m a.s.l.) on silty clay loam soil on $600-\mathrm{m}^{2}$ plots with a gradient of $14 \%$ with three repetitions in a randomised block design. The study investigated the effects of four tillage methods (deep ploughing to $40 \mathrm{~cm}$, superficial ploughing to $20 \mathrm{~cm}$, rotary tillage and no tillage) on soil erosion and showed that at both depths ploughing had a better controlling effect than rotary tillage or no tillage at all. Erosion was observed to the extent of 3.4 and $3.5 \mathrm{Mg} \mathrm{ha}^{-1}$ for ploughing to $40 \mathrm{~cm}$ and to $20 \mathrm{~cm}$, respectively; for rotary tillage and no tillage erosion values were 3.7 and $4.1 \mathrm{Mg} \mathrm{ha}^{-1}$, respectively. Runoff was also less in the ploughed test plots compared to the rototilled and untilled 

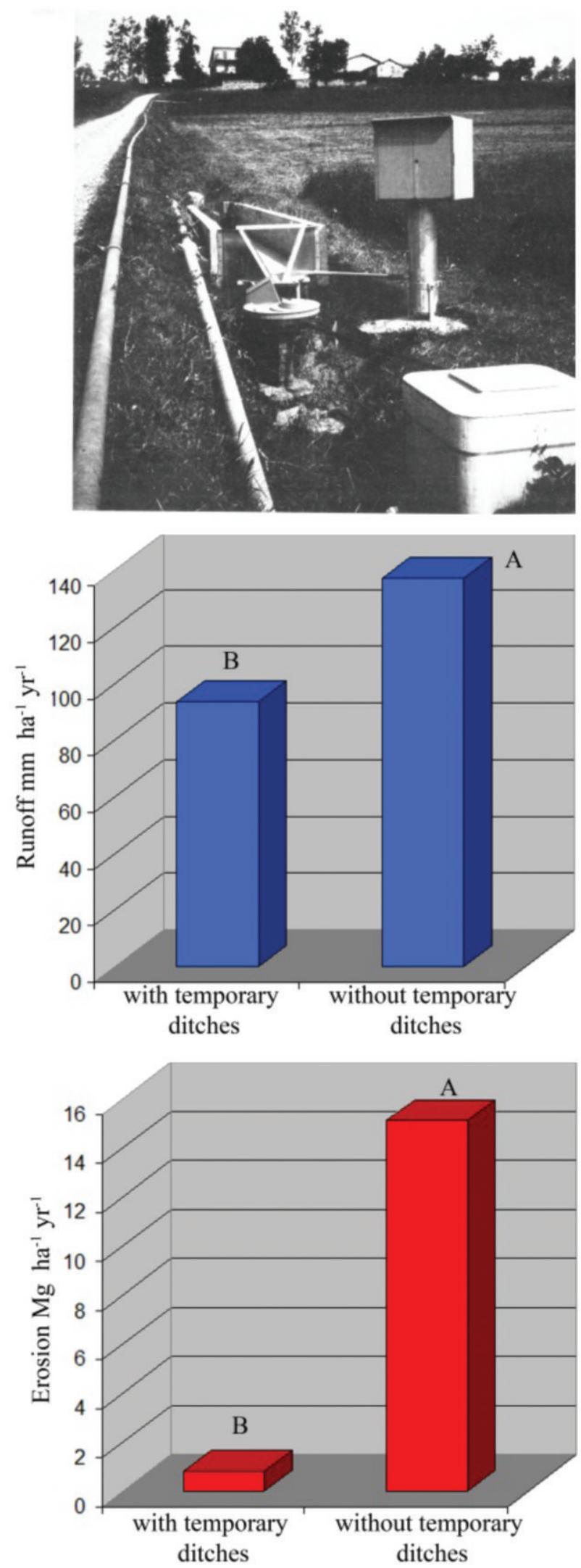

Figure 6. Results of the trial regarding the efficacy of drainage ditches in Guiglia (Bombere farm, Modena, Italy). Means with different letters differ significantly $(P \leq 0.05)$. On the left: Coshocton Wheel type runoff water sampler placed at the outlet of one of the two experimental basins (photo from Chisci and Boschi, 1988). plots. The mean values were $122 \mathrm{~mm}$ and $146 \mathrm{~mm}$ for ploughing to 40 $\mathrm{cm}$ and to $20 \mathrm{~cm}$, respectively, and $162.6 \mathrm{~mm}$ and $188.0 \mathrm{~mm}$ for rotary tillage and no tillage.

During the research carried out by the CRA-ABP in the course of the above-mentioned plot test with winter wheat in Vicarello (Volterra) from 1997 to 1999, the effects of 4 types of soil tillage on erosion and runoff were compared: mouldboard ploughing to $45 \mathrm{~cm}, 30 \mathrm{~cm}$ and 10 cm disc ploughing. In the ploughed plots, the soil was subsequently rototilled to prepare the seed bed. The obtained results (Bazzoffi, original data) show (Figure 7) that mouldboard ploughing (especially mouldboard ploughing to 45) followed by rotary tilling was more effective than disc ploughing for controlling erosion (even though statistical significance was not obtained). Based on these observations it can be confirmed that the excessive decrease of soil roughness caused by rotary tillage should certainly be avoided in order to reduce erosion.

\section{Trials regarding the efficacy of grass strips (by way of derogation from the creation of drainage ditches)}

In order to assess the efficacy of grass strips in controlling runoff and reducing soil erosion, a trial was carried out at the CRA-ABP experimental farm in Vicarello (Volterra) over the period from 1999 to 2002 (Figure 8) (Bazzoffi, original data). The erosion and runoff values of the autumnwinter period (before the start of the wheat's internode elongation) were taken into consideration, as this is the period with the highest occurrence of erosion phenomena owing to soil conditions (presence of small clods due to the preparation of the seed bed, highest occurrence of erosive rainfall and minimal ground cover). The following treatments with (2 replicates for a total of 10 plots) were compared: i) one 3 -m grass strip (36 m of bare soil above and below the grass strip, respectively); ii) two 3-m grass strips ( $23 \mathrm{~m}$ of bare soil above the first grass strip, $23 \mathrm{~m}$ between the first and the second strip, and $23 \mathrm{~m}$ between the second strip and the downhill edge of the plot; iii) one 5-m grass strip ( $35 \mathrm{~m}$ of bare soil above and below the grass strip, respectively); iv) two 5-m grass strips (21.5 m

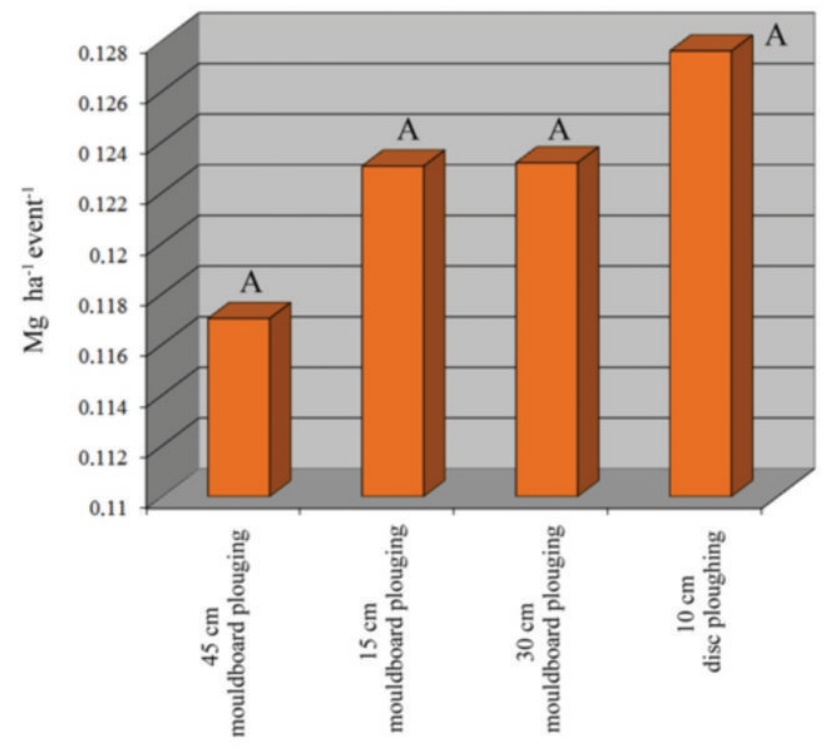

Figure 7. Soil erosion observed in Vicarello (Volterra, Italy) on plots cultivated with winter wheat using different tillage methods. 
of bare soil above the first grass strip, $21.5 \mathrm{~m}$ between the first and the second strip, and $21.5 \mathrm{~m}$ between the second strip and the bottom of the plot); v) bare soil in seed-bed condition (ploughed and disc-harrowed, kept weed-free with herbicides). The statistical analysis of the data (Table 6 and Figure 9) shows a strong, highly significant decrease of erosion due to the effect of the grass strips; erosion decreased from $8.15 \mathrm{Mg} \mathrm{ha}^{-1}$ in the case of bare soil to $0.8 \mathrm{Mg} \mathrm{ha}^{-1}$ in plots with two 3 -m grass strips. The other test plots with grass strips also resulted in a notable, though not statistically significant, reduction of erosion, which on average passed to 1.6 $\mathrm{Mg} \mathrm{ha}^{-1}$, corresponding to a decrease by about 5 times compared to the erosion observed on bare soil. The treatments with a single 5 -metre grass strip, which is similar to the indications provided in the MiPAAF decree 30125 of December 2009 by way of derogation from drainage ditches, was shown to be effective for the control of erosion, decreasing erosion soil loss by about 6.7 times compared to bare soil. With respect to runoff, even though the difference between the mean values does not achieve statistical significance, it appears that the grass strips determined a general decrease of the volumes of runoff water. The exception is the treatment with two 5-metre grass strips, which appears to have increased the runoff compared to the observations made on bare soil. This effect could be due to a decrease of water infiltration in the areas occupied by the grass strips compared to the tilled surfaces.

\section{Assessment of the efficacy of standard 1.1 through the application of erosion models in the AGEA sample control areas in 2009}

The Universal Soil Loss Equation (USLE - Wischmeier and Smith, 1978 ) is the most widely used model in the world for the study of ero-

Table 6. Variance analysis for the comparison of the effects of grass strips on erosion $\left(\mathrm{Mg} \mathrm{ha}^{-1}\right)$ and runoff $\left(\mathrm{m}^{3} \mathrm{ha}^{-1}\right)$.

\begin{tabular}{lccccc} 
ANOVA erosion & SS & DF & MS & F & P \\
Intercept & 1902.07 & 1 & 1902.07 & 12.5746 & 0.0005 \\
treatment & 2222.79 & 4 & 555.70 & 3.6737 & 0.0063 \\
\hline Error & 37059.49 & 245 & 151.26 & & \\
& & & & & \\
ANOVA Runoff & SS & DF & MS & & \\
Intercept & 4768200.00 & 1 & 4768200.00 & 91.0431 & 0.0000 \\
treatment & 511019.30 & 4 & 127754.83 & 2.4393 & 0.0476 \\
\hline Error & 12831381.06 & 245 & 52372.98 & &
\end{tabular}

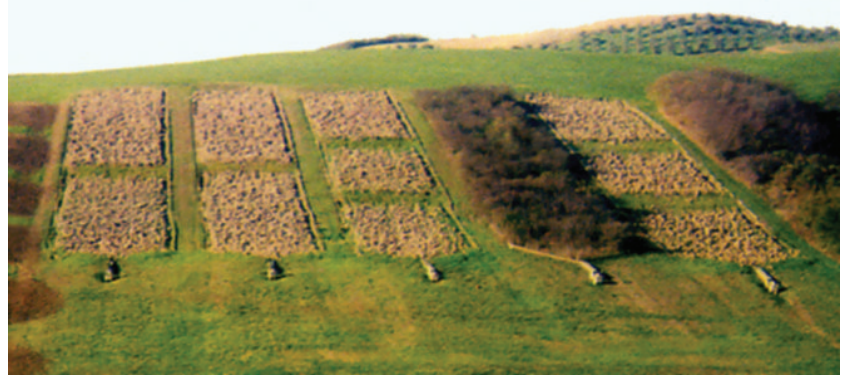

Figure 8. Plot set-up in Vicarello (Volterra, Italy) for the measurement of runoff and erosion. Note the grass strips. sion on different geographic scales. It is a simple empirical model suitable for the estimation of long-term mean soil erosion rates in agricultural fields. Even though this equation has many limitations, it is widely used because of its simplicity of application and of its robustness (Desmet and Govers, 1996), in particular in its revised version RUSLE (Renard et al., 1997).

The USLE/RUSLE model estimates erosion by means of the following empirical equation:

where:

$$
A=R \text { K L S C P }
$$

$A=$ the average annual soil loss $\left(\mathrm{Mg} \mathrm{ha}^{-1} \mathrm{yr}^{-1}\right)$

$R=$ the rainfall erosivity factor $\left(\mathrm{MJ} \mathrm{mm} \mathrm{ha} \mathrm{mo}^{-1} \mathrm{~h}^{-1} \mathrm{yr}^{-1}\right)$

$K=$ the soil erodibility factor $\left(\mathrm{Mg} \mathrm{ha} \mathrm{h}^{-1} \mathrm{MJ}^{-1} \mathrm{~mm}^{-1}\right)$

$L=$ the slope length factor (dimensionless)
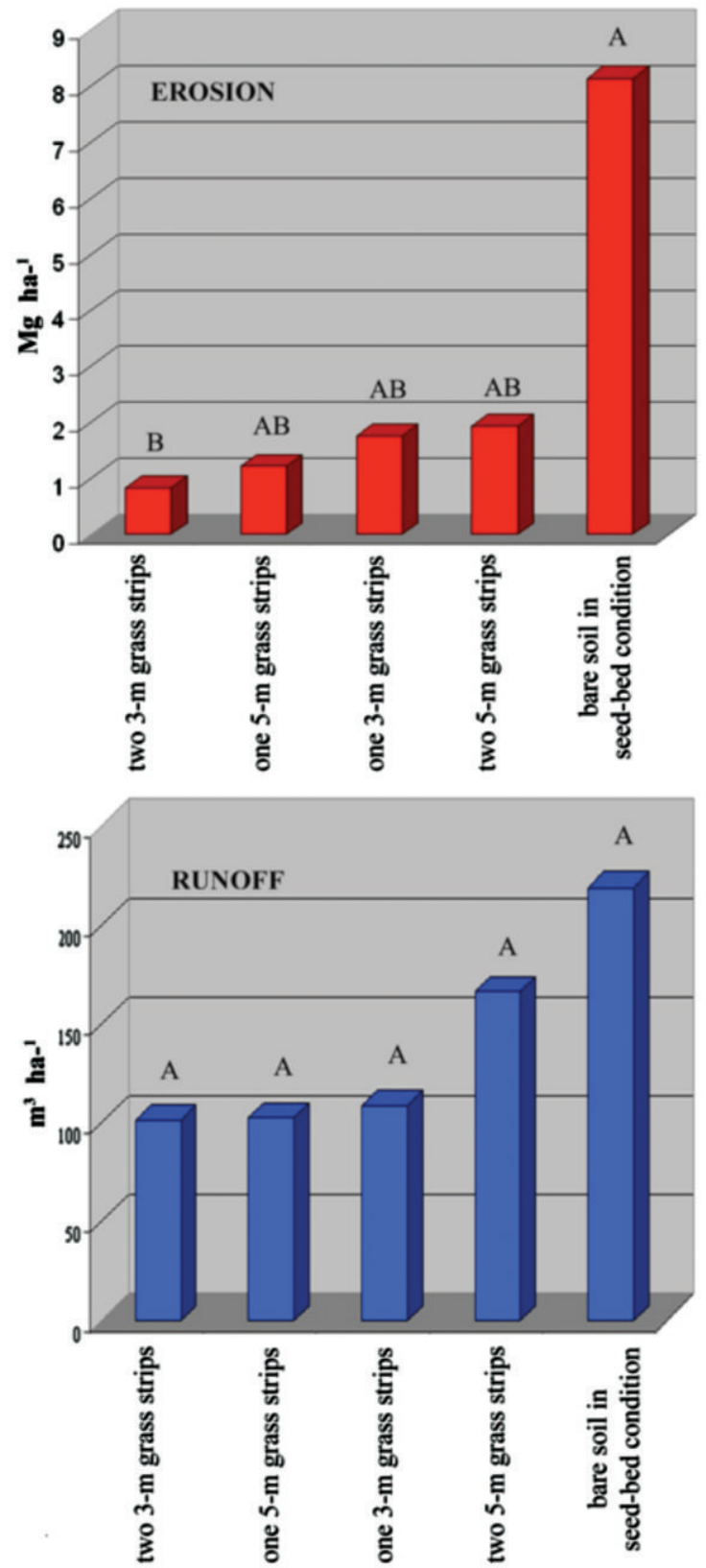

Figure 9. Results of the trial regarding the efficacy of grass strips in Vicarello (Volterra, Italy). 
$S=$ the slope steepness factor (dimensionless)

$C=$ the cover and management factor (dimensionless)

$P=$ the support practice aimed at erosion control factor (dimensionless)

The RUSLE model has been applied by most Italian Regions to create risk maps of potential or actual erosion to aid in the implementation of rural development policies (RDP); in this study it was therefore considered appropriate not to use other prediction models, such as the PESERA model (Gobin et al., 1999), which is indicated in Europe as the reference model but would nonetheless create discrepancies in the interpretation of the results by policy makers in Italy.

Hence, in this work the RUSLE model was used for a scenario analysis in which a comparative assessment of the erosion risk in sample areas was carried out by hypothesising the presence or absence of drainage ditches (spaced at 80 -m intervals as required by standard 1.1a). For the purpose of a meaningful investigation, 60 cereal-growing sites (case studies) were chosen in the sample areas of the 2009 AGEA cross-compliance control. These areas are characterised by a considerable risk of erosion based on soil, morphological and climatic factors.

High-resolution satellite images were made available by AGEA-SIN. The analysis was carried out using ArcGIS 9.3.1 (ESRI) and applying the RUSLE model in accordance with an original method developed specifically for this investigation. The new method simulates the presence of drainage ditches in the sample areas by sinking the digital elevation model along level curves at a distance of 80 metres from each other.

The following layers were used for the application of the method: i) Digital elevation model (DEM) of the national territory with a 20-metre resolution (resampled to $1 \mathrm{~m}$ ) extending over Zone 32 (MATTM, Italian Ministry for the Environment, Land and Sea); ii) Rain erosivity grid with a 75-m cell size (Bazzoffi et al., 2006); iii) Vector layer of soil erodibility (from the BADASUOLI project, personal communication of Edoardo Costantini).

When applying the RUSLE model, the factor $\mathrm{L}$ was calculated using the upslope contributing area concept (Moore and Burch, 1986; Mitasova et al., 1996; Desmet and Govers, 1996), while the factor S was calculated with the Nearing (1997) equation, which can be applied even for gradients $>50 \%$. Figure 10 shows the comparison of the erosion risk in one of the studied areas; this was obtained through the application of the RUSLE model by simulating the absence or presence of drainage ditches. When looking at the statistical comparison of the mean values, it can be seen that in the 60 study areas the presence of
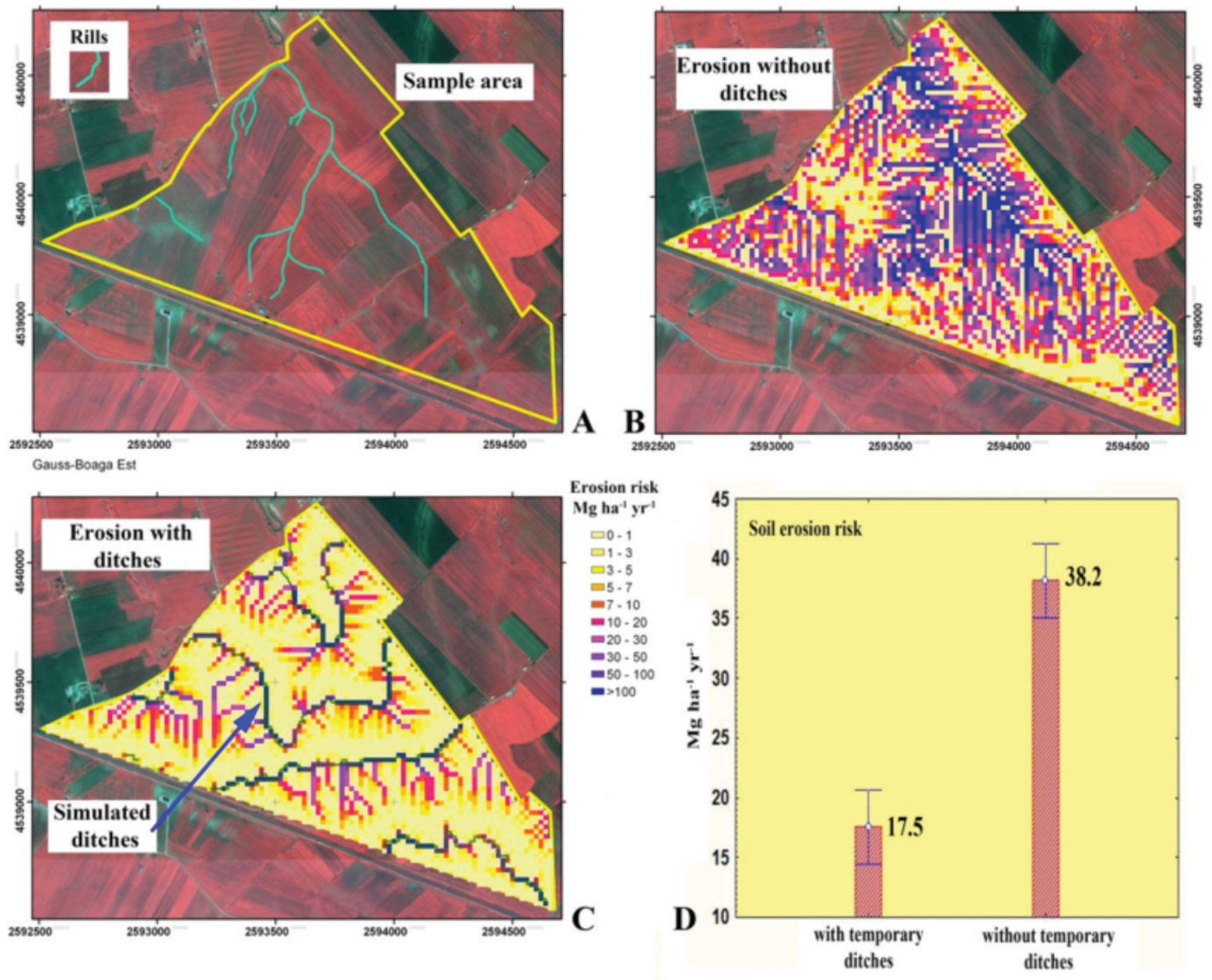

Figure 10. Comparison of the erosion risk in one of the sample areas of the 2009 AGEA control, obtained through the RUSLE model by simulating the absence or presence of drainage ditches at a distance of $80 \mathrm{~m}$ from each other. A) Satellite image showing the erosion rills that developed during the autumn/winter period 2008-2009. B) Erosion risk without drainage ditches. C) Erosion risk with drainage ditches. D) Statistical comparison of the erosion values associated with the grid's cells. 
Table 7. Characteristics of the 60 study areas and results of the application of the RUSLE model in the absence and presence of temporary drainage ditches at a distance of $80 \mathrm{~m}$ from each other. The colours indicate: Green, erosion in the presence of ditches within the OECD limit ( $\left.<6 \mathrm{Mg} \mathrm{ha}^{-1} \mathrm{year}^{-1}\right)$; Yellow, erosion in the presence of ditches between the OECD limit and the USDA limit (between 6 and 11.2 $\mathrm{Mg} \mathrm{ha}^{-1}$ year $\left.^{-1}\right)$; Red, erosion in the presence of ditches above the USDA limit $\left(>11.2 \mathrm{Mg} \mathrm{ha}^{-1} \mathrm{year}^{-1}\right)$.

\begin{tabular}{|c|c|c|c|c|c|c|c|c|c|c|}
\hline $\begin{array}{l}\text { Province } \\
\text { and area } \\
\text { code }\end{array}$ & $\begin{array}{l}\text { Area } \\
\text { (ha) }\end{array}$ & $\begin{array}{c}\mathrm{K} \text { (erodibility) } \\
\left(\mathrm{Mg}_{\mathrm{ha} \mathrm{h}}^{-1}\right. \\
\left.\mathrm{MJ}^{-1} \mathrm{~mm}^{-1}\right)\end{array}$ & $\begin{array}{c}\text { R (erosivity) } \\
\left(\mathrm{MJ} \mathrm{mm} \mathrm{ha-}^{-1}\right. \\
\mathrm{h}^{-1} \mathrm{yr}^{-1} \text { ) }\end{array}$ & $\begin{array}{c}\text { C (cover and } \\
\text { management) } \\
\text { (dimensionless) }\end{array}$ & $\begin{array}{l}\text { Mean } \\
\text { slope } \\
(\%)\end{array}$ & $\begin{array}{l}\text { Erosion risk } \\
\text { without } \\
\text { temporary } \\
\text { ditches } \\
\left(\mathrm{Mg} \mathrm{ha}^{-1} \mathrm{yr}^{-1}\right)\end{array}$ & $\begin{array}{c}\text { Erosion risk } \\
\text { with temporary } \\
\text { ditches } \\
\left(\mathrm{Mg} \mathrm{ha}^{-1} \mathrm{yr}^{-1}\right)\end{array}$ & $\begin{array}{l}\text { Soil erosion risk } \\
\text { decrease due to } \\
\text { temporary } \\
\text { ditches } \\
\left(\mathrm{Mg} \mathrm{ha}^{-1} \mathrm{yr}^{-1}\right)\end{array}$ & $\begin{array}{l}\text { Soil erosion risk } \\
\text { decrease due to } \\
\text { temporary } \\
\text { ditches } \\
(\%)\end{array}$ & $\begin{array}{c}\text { Statistical } \\
\text { significance } \\
\text { of erosion } \\
\text { reduction } \\
\text { due to ditches }\end{array}$ \\
\hline
\end{tabular}

\begin{tabular}{|c|c|c|c|c|c|c|c|c|c|c|}
\hline AG_1 & 26.6 & 0.022 & 1656 & 0.12 & 19.5 & 30.8 & 6.2 & 24.7 & 80.0 & ** \\
\hline AG_2 & 51.9 & 0.022 & 1618 & 0.12 & 13.8 & 19.1 & 7.8 & 11.3 & 59.3 & $* *$ \\
\hline AR_1 & 11.1 & 0.035 & 2041 & 0.12 & 9.2 & 20.7 & 6.6 & 14.0 & 67.9 & ** \\
\hline AR_2 & 9.7 & 0.035 & 1951 & 0.12 & 6.4 & 15.3 & 5.2 & 10.0 & 65.7 & $* *$ \\
\hline BA_2 & 40.5 & 0.035 & 1155 & 0.12 & 4.7 & 6.0 & 1.7 & 4.3 & 71.4 & ** \\
\hline BA_4 & 23.4 & 0.033 & 1091 & 0.12 & 4.3 & 4.5 & 1.3 & 3.2 & 71.0 & ** \\
\hline BA_5 & 15.5 & 0.018 & 1235 & 0.12 & 8.5 & 4.7 & 1.7 & 3.0 & 63.4 & ** \\
\hline BN_1 & 6.2 & 0.022 & 1900 & 0.12 & 11.3 & 12.2 & 5.3 & 7.0 & 57.0 & ** \\
\hline BN_2 & 27.4 & 0.022 & 2457 & 0.12 & 9.8 & 29.6 & 8.5 & 21.2 & 71.4 & $* *$ \\
\hline BN_3 & 23.2 & 0.022 & 2566 & 0.12 & 13.0 & 33.2 & 13.6 & 19.6 & 59.0 & ** \\
\hline BN_4 & 4.8 & 0.022 & 2010 & 0.12 & 11.2 & 12.1 & 5.2 & 6.9 & 57.0 & $* *$ \\
\hline B0_1 & 16.0 & 0.059 & 1736 & 0.12 & 15.3 & 52.3 & 18.7 & 33.6 & 64.3 & ** \\
\hline BO_2 & 21.5 & 0.059 & 1669 & 0.12 & 10.8 & 31.4 & 13.8 & 17.6 & 55.9 & ** \\
\hline B0_3 & 6.4 & 0.053 & 1596 & 0.12 & 16.6 & 45.3 & 10.6 & 34.7 & 76.6 & ** \\
\hline CB_1 & 49.2 & 0.035 & 1032 & 0.12 & 10.2 & 14.8 & 4.1 & 10.7 & 72.2 & $* *$ \\
\hline CB_3 & 53.1 & 0.027 & 1090 & 0.12 & 10.6 & 11.7 & 3.0 & 8.6 & 74.0 & ** \\
\hline CB_4 & 97.4 & 0.022 & 1013 & 0.12 & 16.1 & 17.7 & 4.5 & 13.2 & 74.7 & ** \\
\hline CB_5 & 48.4 & 0.022 & 1107 & 0.12 & 7.5 & 7.6 & 2.0 & 5.6 & 74.1 & $* *$ \\
\hline CB_6 & 24.6 & 0.022 & 1150 & 0.12 & 11.7 & 12.6 & 3.7 & 8.9 & 70.5 & ** \\
\hline CB_7 & 16.7 & 0.022 & 1445 & 0.12 & 12.6 & 13.9 & 5.2 & 8.6 & 62.2 & ** \\
\hline CB_8 & 23.5 & 0.022 & 1643 & 0.12 & 13.5 & 21.1 & 7.6 & 13.6 & 64.1 & ** \\
\hline CB_9 & 34.3 & 0.022 & 1670 & 0.12 & 7.6 & 8.7 & 2.3 & 6.4 & 73.1 & $* *$ \\
\hline CS_1 & 4.8 & 0.034 & 2903 & 0.12 & 9.4 & 17.4 & 9.1 & 8.2 & 47.4 & ** \\
\hline GR_1 & 19.9 & 0.035 & 2646 & 0.12 & 7.3 & 19.7 & 5.9 & 13.9 & 70.3 & ** \\
\hline GR_2 & 22.1 & 0.039 & 2630 & 0.12 & 8.2 & 23.0 & 3.8 & 19.2 & 83.7 & $* *$ \\
\hline GR_3 & 16.7 & 0.047 & 2592 & 0.12 & 4.7 & 15.9 & 4.7 & 11.2 & 70.4 & ** \\
\hline MT_1 & 9.4 & 0.036 & 1660 & 0.12 & 13.1 & 26.4 & 10.3 & 16.1 & 61.0 & $* *$ \\
\hline MT_2 & 32.0 & 0.040 & 1672 & 0.12 & 15.6 & 35.2 & 13.6 & 21.6 & 61.5 & ** \\
\hline MT_3 & 50.3 & 0.059 & 1656 & 0.12 & 7.1 & 18.9 & 7.3 & 11.6 & 61.1 & $* *$ \\
\hline MT_4 & 9.9 & 0.052 & 1550 & 0.12 & 8.4 & 14.2 & 7.4 & 6.9 & 48.2 & ** \\
\hline MT_5 & 12.8 & 0.035 & 1592 & 0.12 & 19.0 & 56.3 & 14.9 & 41.5 & 73.6 & ** \\
\hline MT_6 & 11.6 & 0.018 & 1367 & 0.12 & 15.7 & 15.8 & 5.9 & 9.9 & 62.7 & $* *$ \\
\hline MT_7 & 70.1 & 0.033 & 1090 & 0.12 & 5.5 & 7.1 & 1.7 & 5.4 & 76.3 & ** \\
\hline MT_9 & 27.3 & 0.035 & 1471 & 0.12 & 9.1 & 12.0 & 4.8 & 7.1 & 59.6 & $* *$ \\
\hline PE_1 & 6.5 & 0.035 & 1961 & 0.12 & 16.3 & 29.8 & 9.7 & 20.2 & 67.6 & ** \\
\hline PE_2 & 10.8 & 0.047 & 1784 & 0.12 & 9.6 & 24.2 & 7.7 & 16.5 & 68.3 & $* *$ \\
\hline PE_3 & 45.0 & 0.039 & 1830 & 0.12 & 15.0 & 42.3 & 14.3 & 28.0 & 66.3 & ** \\
\hline PE_4 & 5.9 & 0.035 & 2049 & 0.12 & 19.2 & 30.8 & 9.7 & 21.1 & 68.4 & $* *$ \\
\hline PG_l & 17.1 & 0.059 & 2633 & 0.12 & 12.0 & 58.6 & 19.0 & 39.7 & 67.6 & ** \\
\hline PG_2 & 18.4 & 0.059 & 2583 & 0.12 & 10.1 & 59.1 & 16.6 & 42.5 & 71.9 & ** \\
\hline PG_3 & 22.1 & 0.059 & 2693 & 0.12 & 8.7 & 52.5 & 16.6 & 35.9 & 68.4 & $* *$ \\
\hline PI_1 & 42.7 & 0.035 & 2827 & 0.12 & 7.3 & 25.8 & 6.0 & 19.8 & 76.6 & $* *$ \\
\hline PI_2 & 39.7 & 0.035 & 2805 & 0.12 & 7.0 & 20.4 & 6.1 & 14.3 & 70.1 & $* *$ \\
\hline PI_3 & 54.3 & 0.035 & 2766 & 0.12 & 10.3 & 29.8 & 8.7 & 21.1 & 70.9 & ** \\
\hline
\end{tabular}

Continued on next page. 
Table 7. Continued from previous page.

\begin{tabular}{|c|c|c|c|c|c|c|c|c|c|c|}
\hline $\begin{array}{l}\text { Province } \\
\text { and area } \\
\text { code }\end{array}$ & $\begin{array}{l}\text { Area } \\
\text { (ha) }\end{array}$ & $\begin{array}{c}\mathrm{K} \text { (erodibility) } \\
\left(\mathrm{Mg} \mathrm{ha} \mathrm{h}^{-1}\right. \\
\left.\mathrm{MJ}^{-1} \mathrm{~mm}^{-1}\right)\end{array}$ & $\begin{array}{c}\mathrm{R} \text { (erosivity) } \\
\text { (MJ mm ha- } \\
\mathrm{h}^{-1} \mathrm{yr}^{-1} \text { ) }\end{array}$ & $\begin{array}{c}\text { C (cover and } \\
\text { management) } \\
\text { (dimensionless) }\end{array}$ & $\begin{array}{c}\text { Mean } \\
\text { slope } \\
(\%)\end{array}$ & $\begin{array}{l}\text { Erosion risk } \\
\text { without } \\
\text { temporary } \\
\text { ditches } \\
\left(\mathrm{Mg} \mathrm{ha}^{-1} \mathrm{yr}^{-1}\right)\end{array}$ & $\begin{array}{c}\text { Erosion risk } \\
\text { with temporary } \\
\text { ditches } \\
\left(\mathrm{Mg} \mathrm{ha}^{-1} \mathrm{yr}^{-1}\right)\end{array}$ & $\begin{array}{c}\text { Soil erosion risk } \\
\text { decrease due to } \\
\text { temporary } \\
\text { ditches } \\
\left(\mathrm{Mg} \mathrm{ha}^{-1} \mathrm{yr}^{-1}\right)\end{array}$ & $\begin{array}{l}\text { Soil erosion risk } \\
\text { decrease due to } \\
\text { temporary } \\
\text { ditches } \\
(\%)\end{array}$ & $\begin{array}{l}\text { Statistical } \\
\text { significance } \\
\text { of erosion } \\
\text { reduction } \\
\text { due to ditches }\end{array}$ \\
\hline PR_1 & 11.7 & 0.047 & 2556 & 0.12 & 12.1 & 56.8 & 20.6 & 36.2 & 63.7 & $* *$ \\
\hline PR_2 & 15.5 & 0.047 & 2544 & 0.12 & 10.6 & 37.5 & 12.8 & 24.7 & 65.8 & $* *$ \\
\hline PU_1 & 13.7 & 0.053 & 2654 & 0.12 & 17.2 & 71.3 & 21.5 & 49.8 & 69.9 & $* *$ \\
\hline PU_2 & 6.5 & 0.035 & 2821 & 0.12 & 17.9 & 46.9 & 13.1 & 33.8 & 72.1 & $* *$ \\
\hline PU_3 & 17.1 & 0.035 & 2824 & 0.12 & 20.1 & 72.7 & 19.6 & 53.1 & 73.1 & $* *$ \\
\hline PU_4 & 11.6 & 0.035 & 2761 & 0.12 & 25.5 & 89.2 & 34.2 & 55.0 & 61.6 & $* *$ \\
\hline PU_5 & 7.3 & 0.059 & 2745 & 0.12 & 18.0 & 118.3 & 30.2 & 88.1 & 74.5 & $* *$ \\
\hline PU_ 6 & 3.3 & 0.043 & 2753 & 0.12 & 13.0 & 26.8 & 14.7 & 12.1 & 45.2 & $* *$ \\
\hline PU_7 & 26.1 & 0.059 & 2736 & 0.12 & 20.2 & 114.4 & 27.9 & 86.5 & 75.6 & $* *$ \\
\hline PU_8 & 25.1 & 0.058 & 2714 & 0.12 & 18.6 & 135.3 & 31.3 & 103.9 & 76.8 & $* *$ \\
\hline PZ_1 & 112.1 & 0.035 & 1490 & 0.12 & 3.6 & 9.0 & 2.1 & 6.9 & 77.1 & $* *$ \\
\hline PZ_2 & 110.0 & 0.035 & 1479 & 0.12 & 4.4 & 10.9 & 2.0 & 8.9 & 81.9 & $* *$ \\
\hline TE_1 & 5.4 & 0.047 & 1747 & 0.12 & 9.7 & 18.9 & 7.4 & 11.4 & 60.5 & $* *$ \\
\hline TE_2 & 11.9 & 0.035 & 1713 & 0.12 & 21.1 & 44.0 & 19.6 & 24.5 & 55.5 & $* *$ \\
\hline TE_3 & 19.4 & 0.035 & 1703 & 0.12 & 14.9 & 35.7 & 12.8 & 22.9 & 64.2 & $* *$ \\
\hline TE_4 & 13.0 & 0.035 & 1700 & 0.12 & 10.8 & 24.6 & 6.8 & 17.8 & 72.3 & $* *$ \\
\hline Overall & 26.5 & & & & & 32.9 & 10.3 & 22.6 & 67.4 & \\
\hline
\end{tabular}

drainage ditches on average reduces erosion by $67 \%$ (Figure 11). In 22 study areas erosion was below the tolerance limit of $6 \mathrm{Mg} \mathrm{ha}^{-1}$ year-1 established by the OECD, in 17 areas it was between the OECD limit and the USDA limit (that is between 6 and $11.2 \mathrm{Mg} \mathrm{ha}^{-1}$ year-1), and in the remaining 21 areas erosion was above the USDA limit $(>11.2 \mathrm{Mg}$ $\mathrm{ha}^{-1}$ year-1) but even so did not reach alarming levels (the highest value found was $34.2 \mathrm{Mg} \mathrm{ha}^{-1}$ year-1), as these erosion values could easily be reduced to within the limits by slightly decreasing the distance between the ditches.

\section{Discussion and Conclusions}

The standard was found to be effective from a hydraulic point of view, as the results demonstrated the efficacy of temporary ditches, which can be created with the most common ditching tools available on farms, in controlling runoff water. The Standard is also very effective for erosion control as long as it is applied taking into account the characteristics of the area (by establishing an adequate distance between the ditches). Grass strips realised by way of derogation from temporary drainage ditches were also found to be effective for the control of runoff and erosion. Further confirmation, which is representative for the Italian territory, is obtained from the results of the GIS analysis (Table 7). The literature (Landi et al., 1982) and the research carried out in Italy show that the problem of erosion control must be handled in the context of all agronomic practices that involve the soil. In particular, tilling of the soil complements the agricultural land set-up Systems for soil and water conservation, improving water availability to plants and making erosion control more efficient. In this regard, particular attention must be paid to the main tilling depth, which with a view to erosion control should not be excessively reduced; in any case, tilling

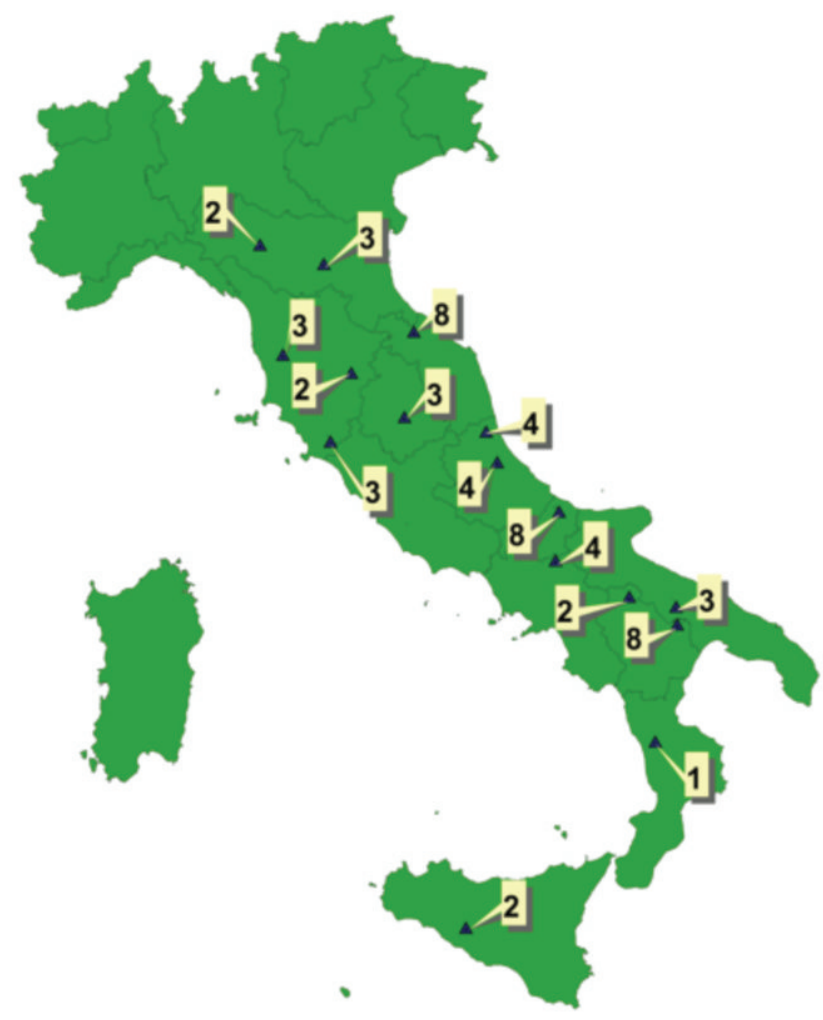

Figure 11. Location of the 60 trial areas. The numbers indicate how many study areas are present at the sites identified by the triangles. 
should be carried out according to conservative practices for the reduction of erosion and for conserving soil organic matter (for example without turning over the soil).

The new standard 1.2, titled minimum soil cover, of the 2009 MiPAAF legislation, already takes into account the indication of an integrated approach to agronomic activities able to control soil erosion. In fact, it imposes new obligations in synergy with the creation of temporary drainage ditches for reducing erosion, such as the obligation to ensure a ground vegetation cover for at least 90 consecutive days during the period from 15 September to 15 May of the following agricultural year, or as an alternative to adopt soil protection methods (such as heavy or light chisel ploughing instead of mouldboard ploughing, keeping crop residue on the soil surface after the harvest, etc.).

The current Standard does not provide indications about the correct spacing and depth of temporary ditches to make them last and function correctly until the harvest of the crop. Instead the Standard leaves the difficult, if not impossible, task of determining these values to the farmer. On the other hand, it must be said that to date scientific literature and technical manuals have provided rather vague indications in this regard. This affected national and regional cross-compliance Standards, which did not provide farmers with suitable indications for applying the Standard. We therefore consider it essential for the farm advisory system to provide farmers with the information necessary for the realisation of temporary drainage ditches (depth and section that can be obtained with the most widespread types of ditch diggers) so that these ditches are effective and maintain their hydraulic efficacy throughout the entire production period of the cultivation in progress. These values can be inferred from Table 4, which indicates the maximum runoff peaks that the ditch must be able to handle in relation to the ditch's length, the slope gradient and the distance between ditches. This would also be useful for cross-compliance control by the AGEA and regional control bodies. Strengthening the role of farm advisory services is important to support farmers in meeting the GAEC requirements. In fact, ditches need to be realized in a correct way in order to be effective against soil erosion.

Since it has been demonstrated that soil erosion is efficiently controlled through the preservation of the soil's roughness (cloddiness) and by leaving the residues of the previous crop as a cover, rotary tilling should be avoided (maybe even abolished) for the preparation of the seed bed in sloping areas. We therefore consider it necessary to expand Norm 1 through the introduction of a new Standard that would prohibit rotary tilling of the soil and the cultivation of small-seeded crops that require roller compaction (such as rapeseed) on sloping land with a gradient $>5 \%$.

As said above, it must be considered that the GAEC Standards are minimal actions requested to farmers in order to keep the environmental menaces just within the tolerance thresholds, with no further production of environmental goods and services.

Although the results obtained are very promising, it should be considered that the Standard 1.1 alone can not effectively counteract soil erosion that occurs in extreme events of rainfall. This is particularly important given that the frequency of extreme events is being increased by climatic change. For this reason, and to achieve optimal results, the standard 1.1 needs to be integrated by appropriate and synergic agrienvironmental measures (e.g., conservation tillage, cover crops, etc.).

\section{References}

Bagarello V., Birtone M., Ferro V., Giordano G., Pampalone V., Pomilla S., 2009. Effetto della lunghezza della parcella sulla perdita di suolo. IX Convegno Nazionale dell'Associazione Italiana di Ingegneria
Agraria, Ischia Porto, Italy, memoria n. 1-1.

Basso F., Postiglione L., Carone F., 1986. Lavorazione del terreno in ambiente collinare dell'Italia meridionale. Un triennio di prove sull'erosione del suolo e sulla produzione del frumento. Riv. Agron. 20:218-225.

Bazin, H.E. 1897. Étude d'une nouvelle formule pour calculer le débit des canaux découverts. Mémoire No. 41. Annales des ponts et chaussées 14:20-70.

Bazzoffi P., 1993a. Fagna-type Hydrological unit for runoff measurement and sampling on experimental plots. Soil Technology 6:251259.

Bazzoffi P., 1993b. The enhanced Fagna-type hydrological unit for measurement and sam $\neg$ pling of runoff waters. pp 195-204 in Proc. Int. Workshop on Soil Erosion in Semi-Arid Mediterranean Areas. CNR Ed., ESSC-CSEI, Taormina, Italy.

Bazzoffi P., 2009. Soil erosion tolerance and water runoff control: minimum environmental Standards. Regional Environ. Change 9:169 179.

Bazzoffi P., Abbattista F., Vanino S., Napoli R., 2006. The new Italian Atlas of sediment yield from basins. Page 493 in Proc. 18th World Congr. of Soil Science Abstracts, Philadephia, PA, USA.

Bazzoffi P., Pellegrini S., 1992. Caratteristiche delle piogge influenti sui processi erosivi nel periodo 1964-1990 in un ambiente della valle dell'Era (Toscana). Evoluzione climatica e modelli previsionali. Annali Istituto Sperimentale per lo Studio e la Difesa del Suolo. 20:161-182.

Bazzoffi P., Pellegrini S., Chisci G., Papini R., Scagnozzi A., 1997. Erosione e deflussi a scala parcellare e di bacino in suoli argillosi a diversa utilizzazione nella val d'Era. Agricoltura Ricerca 170:5-20.

Buffoni L., Brunetti M., Mangianti F., Maugeri M., Monti F., Nanni T., 2003. Ricostruzione del clima italiano negli ultimi 130 anni e scenari per il XXI secolo. Atti Workshop CLIMAGRI - Cambiamenti climatici e agricoltura, Cagliari, Italy.

Calzecchi Onesti A., 1957. Sistemazioni in collina. R.E.D.A. Ed., Roma, Italy.

Chezy A., 1776. Formule pour trouver la vitesse de l'eau conduit dan une rigole donnée. Dossier 847 (MS 1915) of the manuscript collection of the École Nationale des Ponts et Chaussées, Paris, France. Reproduced in: Mouret, G. (1921). Antoine Chézy: histoire d'une formule d'hydraulique. Annales des Ponts et Chaussées 61:165-269.

Chisci G., Boschi V., 1988. Runoff and erosion control with hill farming in the sub-coastal Apennines climate. Soil Till. Res. 12:105-120.

Chow V.T., 1964. Handbook of Applied Hydrology: A Compendium of Water-resources Technology. McGraw-Hill, New York, NY, USA.

Desmet P.J.J., Govers G., 1996. A GIS procedure for automatically calculating the USLE LS factor on topographically complex landscape units. J. Soil Water Conserv. 51:427-433.

Di Stefano C., Di Piazza G.V., Ferro V., 2008. Field testing of a simple flume (SMBF) for flow measurement in open channels. J. Irrig. Drain. E-ASCE 134:235-240.

Gasparini M., 1959. Aspetti agronomici della meccanizzazione collinare in toscana. pp 39-58 in Atti Conv. Meccanizzazione collinare, Firenze, Italy.

Gasparini M., 1964. La esaltazione della capacità produttiva del terreno attraverso la perfezione del lavoro meccanico e la regimazione delle acque profonde. pp 29-41 in Atti Conv. Naz. sulla Meccanizzazione Agr. nei terreni declivi, Pesaro, Italy.

Gasparini M., 1970. Evoluzione delle sistemazioni idraulico-agrarie nelle terre declivi. In: Difesa e conservazione del suolo dalle erosioni idrogeologiche. Ist. Tecn. Prop. Agr. Ed., Roma, Italy.

Gobin A., Govers G., Kirkby M.J., Le Bissonnais Y., Kosmas C., Puidefabregas J., Van Lynden G., Jones R.J.A., 1999. PESERA Project Technical Annex. Contract No.: QLKS-CT-1999-01323, 
European Commission.

Landi R., 1978. Struttura e miglioramento dei terreni argillosi. In: L'utilizzazione dei terreni argillosi dell'Appennino. ISEA Ed., Bologna, Italy.

Landi R., 1979. Riflessioni sull'evoluzione del pensiero agronomico in materia di fertilità. L'Italia Agricola 116:70-91.

Landi R., 1980. Sistemazioni collinari. L'Italia Agricola 117:122-142.

Landi R., 1984. Regimazione idraulico-agraria e conservazione del suolo. Riv. Agron. 18:147-174.

Landi R., Mattei Scarpaccini F., Raso E., 1982. Interventi sistematori nei terreni collinari. Atti Conv. Finale C.N.R. Conservazione del Suolo, Roma, Italy.

Lisa L., Parena S., 1994 - Forme di allevamento dei vigneti collinari piemontesi idonee a una razionale meccanizzazione. Vignevini 21:47-54.

Mannocchi F., Todisco F., Vergni L., Vinci A., 2009. Misura della perdita di suolo a scala parcellare in una stazione sperimentale umbra. IX Conv. Naz. Associazione Italiana di Ingegneria Agraria, Ischia Porto, Italy, memoria n. 1-2.

Mitasova H., Hofierka J., Zlocha M., Iverson R.L., 1996. Modelling topographic potential for erosion and deposition using GIS. Int. J. Geogr. Inf. Syst. 10:629-641.

Monotti M., 1980. Affossatura, dimensionamento, realizzazione. L'Italia Agricola 117:72-84.

Moore I., Burch G., 1986. Modelling erosion and deposition: topographic effects. Trans. ASAE 29:1624-1640.

Nearing M.A., 1997. A single continuous function for gradient steepness influence on soil loss. Soil Sci. Soc. Am. J. 61: 917-919.

NRCS-USDA Natural Resources Conservation Service, 1999. National Soil Survey Handbook-Title 430-VI. Available from: http://www.stat- lab.iastate.edu/soils/nssh/

OECD, 2001. Environmental indicators for agriculture. Methods and results, vol 3. In: OECD (ed) Agriculture and food. OECD Publ., Paris, France.

Oliva A., 1938. Le sistemazioni idraulico agrarie dei terreni asciutti di pianura, collina e montagna. Biblioteca della bonifica integrale, Vol. 5. S.A.G. Barbera Ed. Firenze, Italy.

Oliva A., 1948a. La sistemazioni dei terreni. Edagricole Ed., Bologna, Italy.

Oliva A., 1948b. Trattato di Agricoltura generale. Aetas Ed., Milano, Italy.

Periccioli, M., 1956. Sistemazione della collina in funzione dei nuovi mezzi agronomici. Atti Accademia dei Georgofili, dispense III e IV.

Renard K.G., Foster G.R., Weesies G.A., McCool D.K., Yoder D.C., 1997. Predicting Soil Erosion by Water: A guide to conservation planning with the Revised Universal Soil Loss Equation (RUSLE). USDA, Agricultural Handbook No. 703, Government Printing Office, Washington, DC, USA.

Ridolfi C., 1934. Memorie sulla bonifica collinare. Pubbl. sponsored by Accademia dei Georgofili. Ramo Editoriale degli Agricoltori, Vol. XVIII, Roma, Italy.

Wischmeier W.H., Smith D.D., 1978. Predicting rainfall erosion losses A guide for conservation planning. USDA, Agricultural Handbook No. 537, Government Printing Office, Washington, DC, USA.

Zanchi C., 1981. Influenza del diverso carico di pascolamento bovino sul ruscellamento superficiale, sul drenaggio e sulle asportazioni di suolo:esperienze pluriennali nel centro sperimentale di Fagna (Firenze). Annali Istituto Sperimentale per lo Studio e la Difesa del Suolo 12:193-216. 